\title{
Review
}

\section{Technology Acceptance in Healthcare: A Systematic Review}

\author{
Adi A. AlQudah (1), Mostafa Al-Emran *(1) and Khaled Shaalan (1) \\ Faculty of Engineering \& IT, The British University in Dubai, Dubai 345015, United Arab Emirates; \\ adi.alqudah@ieee.org (A.A.A.); khaled.shaalan@buid.ac.ae (K.S.) \\ * Correspondence: mostafa.alemran@buid.ac.ae
}

Citation: AlQudah, A.A.; Al-Emran,

M.; Shaalan, K. Technology

Acceptance in Healthcare: A

Systematic Review. Appl. Sci. 2021, 11 10537. https://doi.org/10.3390/

app112210537

Academic Editors: Byung Yong Jeong, Ken Nah and Yonghwan Pan

Received: 6 October 2021

Accepted: 3 November 2021

Published: 9 November 2021

Publisher's Note: MDPI stays neutral with regard to jurisdictional claims in published maps and institutional affiliations.

Copyright: (c) 2021 by the authors. Licensee MDPI, Basel, Switzerland. This article is an open access article distributed under the terms and conditions of the Creative Commons Attribution (CC BY) license (https:// creativecommons.org/licenses/by/ $4.0 /)$.

\begin{abstract}
Understanding the factors affecting the use of healthcare technologies is a crucial topic that has been extensively studied, specifically during the last decade. These factors were studied using different technology acceptance models and theories. However, a systematic review that offers extensive understanding into what affects healthcare technologies and services and covers distinctive trends in large-scale research remains lacking. Therefore, this review aims to systematically review the articles published on technology acceptance in healthcare. From a yield of 1768 studies collected, 142 empirical studies have met the eligibility criteria and were extensively analyzed. The key findings confirmed that TAM and UTAUT are the most prevailing models in explaining what affects the acceptance of various healthcare technologies through different user groups, settings, and countries. Apart from the core constructs of TAM and UTAUT, the results showed that anxiety, computer self-efficacy, innovativeness, and trust are the most influential factors affecting various healthcare technologies. The results also revealed that Taiwan and the USA are leading the research of technology acceptance in healthcare, with a remarkable increase in studies focusing on telemedicine and electronic medical records solutions. This review is believed to enhance our understanding through a number of theoretical contributions and practical implications by unveiling the full potential of technology acceptance in healthcare and opening the door for further research opportunities.
\end{abstract}

Keywords: technology acceptance; technology adoption; healthcare; systematic review

\section{Introduction}

Technology acceptance is defined as opposite to the term rejection, where it signifies the positive decision toward using an innovative solution [1,2]. Technology acceptance is concerned with the psychological status of a person regarding the intention to use a specific technology [3]. A user's acceptance of technology is significant at any time and not only at the design phase or directly after implementation. Non-stop changes will occur in the information systems, their designs, working environments, and potential users. Users' needs may also differ due to these changes and other social or cultural issues [4].

There is no doubt on how information technologies have proliferated in the healthcare sector [5]. Information technologies are important to enhance the quality of healthcare services and improve patients' satisfaction. Moreover, the staff using the technology in the healthcare domain is an essential issue, since information technologies play a vital role in increasing their work efficiency and effectiveness [6]. That is why it is crucial to determine and understand how people react to the emergence of new technologies. The low levels of acceptance for particular information technology can lead to failure or delay in implementing that technology. Additionally, the lack of acceptance of technology in healthcare can negatively impact its key objectives [7].

Over the years, the acceptance of different information technologies and applications has been explored in the healthcare field. These technologies include internet-based health websites [8], picture archiving and communication systems (PACs) [9], mobile applications [7], telemedicine technologies, and electronic health records [10]. As is the case with other technologies, healthcare technologies were examined using different technology 
acceptance models and theories. This is because those theories and models offer a better understanding of the users' behaviors toward a specific technology or service through the factors underpinning them [11]. It is believed that the identification of these factors would enhance the effectiveness of healthcare technologies by allowing scholars to investigate the technical, social, and cultural aspects and understand the correlation between those factors and users' readiness to use healthcare systems. Therefore, this study aims to systematically review the studies that empirically evaluated the different technologies in healthcare in relation to technology acceptance models and theories. Stemming from this aim, the authors intend to answer the following research questions:

RQ1. What are the prevailing technology acceptance models and theories explored in the healthcare domain?

RQ2. What are the key factors affecting technology acceptance in the healthcare domain?

RQ3. What are the primary confirmed relationships among the influential factors in the past studies?

RQ4. What are the leading information technologies studied and their relationships with countries and participants?

RQ5. How are the reviewed studies distributed across the regions and countries of technology implementation?

RQ6. What is the progress of technology acceptance studies in healthcare?

\section{Literature Review}

During the last three decades, various theoretical models and their extensions have been designed to understand the acceptance levels and individuals' behaviors toward different technologies in various disciplines [6]. These models introduced different factors to understand their effect on the user's acceptance of technology. Those theories include but are not limited to the theory of reasoned action (TRA) [12], the technology acceptance model (TAM) [13-15], extensions of TAM [16,17], the unified theory of acceptance and use of technology (UTAUT) [18], social cognitive theory (SCT) [19,20], the theory of interpersonal behavior (TIB) [21], the perceived characteristics of innovating theory [22], the theory of planned behavior (TPB) [23], the model of PC utilization [24], the motivational model [25], innovation diffusion theory (IDT) [26], and Igbaria's model [27].

Among the aforementioned theories and models, the UTAUT is known as the most relevant [28] and the most actively used model in technology acceptance studies in the healthcare domain $[28,29]$. Apart from the healthcare domain, TAM is also recognized as the gold standard model across several technologies [30-32]. On the other hand, UTAUT has shown $20-30 \%$ better explanatory power than TAM, which means $40-50 \%$ of the explanatory power regarding the behavioral intention of end-users [18,31].

Several reviews were conducted to analyze the technology acceptance models and their related constructs/factors in healthcare. It is impossible to ignore those reviews. As seen in Table 1, the review studies have mainly discussed one specific technology acceptance model except for two review studies [33,34]. Besides, only one study focused on the classification of studies based on the examined technologies, participants, and country of implementation [6]. For instance, telehealth solutions were mainly studied from the perspective of older populations [35], with little attention paid to the developing countries. There is an increasing number of healthcare services, which has resulted from the increment of population ages $[36,37]$. To make it distinct, this review provides a broader view for understanding healthcare technologies and identifies the potential gaps in technology acceptance in healthcare.

It is beneficial to have a general review exploring multiple technology acceptance models instead of focusing on one acceptance model (e.g., TAM). Additionally, reviewing different information technologies instead of only one technology (e.g., electronic medical records) is essential to recognize a plethora or gap in the research. Therefore, this review study attempts to present a fresh overview of the literature of technology acceptance in 
the healthcare domain by classifying the collected studies based on the utilized technology acceptance models, the studied information technologies, participants, and countries of implementation. Additionally, this study aims to identify the prevailing acceptance models, the most utilized factors, and the most confirmed relationships to address the literature gaps and assist further research in building integrated models for technology acceptance in the healthcare domain.

As an example for the included studies, Tubaishat [38] has studied the acceptance of electronic health records (EHRs) through a self-administered questionnaire filled by 1539 nurses from 15 hospitals in Jordan. The utilized research model was the original TAM. A multiple linear regression analysis was used to explore nurses' perceptions regarding the ease of use and usefulness of the solution. It was found that the intention to use is influenced by the perceived ease of use and perceived usefulness. The study was limited to nurses without including other medical staff, such as physicians, pharmacists, or laboratory staff.

Hadadgar et al. [39] have explored 146 general practitioners' (GPs) intention to use the e-learning continuing medical education (e-CME). Based on the theory of planned behavior (TPB), the results revealed that attitudes and perceived behavioral control factors significantly influence the intention to use the e-CME solution. The study included only one user group (i.e., GPs), with a limited sample compared to the optimum sample for factor analysis. Further, Perlich et al. [29] have discussed the acceptance of interactive documentation systems by therapists and patients in an addiction therapy center in Germany. The study relied on extending the UTAUT model with the attitude construct. The key results indicated that attitude is the strongest predictor of intention to use.

Table 1. Previous review studies on technology acceptance in healthcare.

\begin{tabular}{|c|c|c|c|c|c|}
\hline Source & $\begin{array}{l}\text { Multiple } \\
\text { Acceptance } \\
\text { Models }\end{array}$ & $\begin{array}{c}\text { Multiple } \\
\text { Technologies }\end{array}$ & Databases & Coverage & Aim \\
\hline$[30]$ & - & $\checkmark$ & $\begin{array}{l}16 \text { datasets (names } \\
\text { not reported) }\end{array}$ & $\begin{array}{l}\text { Before July } 2008 \\
\text { (not clearly } \\
\text { reported) }\end{array}$ & $\begin{array}{c}\text { Literature review of } 20 \text { articles to study } \\
\text { the application of TAM in the } \\
\text { healthcare domain. }\end{array}$ \\
\hline [40] & - & - & $\begin{array}{l}\text { PubMed, EMBASE, CINAHL, } \\
\text { Business Source Premier, } \\
\text { Science Citation Index, Social } \\
\text { Sciences Citation Index, } \\
\text { Cochrane Library, ABI/Inform, } \\
\text { and PsychINFO }\end{array}$ & 1999-2009 & $\begin{array}{l}\text { Systematic review for } 60 \text { studies to explore } \\
\text { the barriers and facilitators } \\
\text { to implementation. }\end{array}$ \\
\hline [41] & - & $\checkmark$ & $\begin{array}{c}\text { MEDLINE, EMBASE, CINAHL, } \\
\text { Cochrane, Ovid, DARE, Biosis } \\
\text { Previews, PsycINFO, HSTAT, } \\
\text { ERIC, ProQuest, ISI Web of } \\
\text { Knowledge, LILACS, } \\
\text { and Ingenta }\end{array}$ & 19-0-2007 & $\begin{array}{l}\text { Systematic review for } 101 \text { studies to } \\
\text { explore the factors that facilitate or limit } \\
\text { the implementation of ICTs in } \\
\text { clinical settings. }\end{array}$ \\
\hline [42] & - & $\checkmark$ & $\begin{array}{l}\text { MEDLINE, EMBASE, CINAHL, } \\
\text { PSYCINFO, and the } \\
\text { Cochrane Library }\end{array}$ & 19-5-2009 & $\begin{array}{l}\text { Systematic review for } 37 \text { review studies to } \\
\text { identify the barriers and facilitators to } \\
\text { e-health implementation and outstanding } \\
\text { gaps in the literature. }\end{array}$ \\
\hline [43] & - & $\checkmark$ & $\begin{array}{c}\text { Science Direct, Springer, } \\
\text { TÜBĐTAK EKUAL, Taylor and } \\
\text { Francis, EBSCO Host, } \\
\text { and Blackwell }\end{array}$ & 19-9-2010 & $\begin{array}{l}\text { Qualitative review to analyze } 50 \text { articles to } \\
\text { study the possible predictors of TAM. }\end{array}$ \\
\hline [33] & $\checkmark$ & $\checkmark$ & $\begin{array}{l}\text { ACM Digital Library, CINAHL, } \\
\text { IEEE Xplore, MEDLINE, } \\
\text { PsycINFO, Scopus, and Web } \\
\text { of Science }\end{array}$ & Not specified & $\begin{array}{l}\text { Systematic review for } 16 \text { studies provides } \\
\text { an overview of factors that influence the } \\
\text { acceptance of electronic technologies that } \\
\text { support older adults. }\end{array}$ \\
\hline
\end{tabular}


Table 1. Cont.

\begin{tabular}{|c|c|c|c|c|c|}
\hline Source & $\begin{array}{l}\text { Multiple } \\
\text { Acceptance } \\
\text { Models }\end{array}$ & $\begin{array}{c}\text { Multiple } \\
\text { Technologies }\end{array}$ & Databases & Coverage & Aim \\
\hline [44] & - & - & $\begin{array}{c}\text { PubMed, EMBASE, } \\
\text { CINAHL, and PsychINFO }\end{array}$ & 20-0-2014 & $\begin{array}{l}\text { Systematic review for } 33 \text { studies to } \\
\text { explore the factors influencing } \\
\text { healthcare professionals' adoption of } \\
\text { mobile health applications. }\end{array}$ \\
\hline \multirow{2}{*}{ [45] } & \multirow{2}{*}{-} & \multirow{2}{*}{ - } & \multirow{2}{*}{$\begin{array}{c}\text { Google Scholar } \\
\text { Med-line, Embase, CINAHL, } \\
\text { PsycINFO, and Scopus }\end{array}$} & $20-0-2015$ & \multirow{2}{*}{$\begin{array}{l}\text { Systematic review for } 44 \text { studies to } \\
\text { review the main barriers to adopt } \\
\text { assistive technologies by older adults. }\end{array}$} \\
\hline & & & & 19-6-2015 & \\
\hline [6] & - & $\checkmark$ & $\begin{array}{c}\text { Web of Science, PubMed, } \\
\text { and Scopus }\end{array}$ & 19-9-2017 & $\begin{array}{c}\text { Systematic review to analyze } \\
134 \text { TAM-based studies in health } \\
\text { information systems. The study aims } \\
\text { to understand the existing research } \\
\text { and debates as is relevant to TAM in } \\
\text { the healthcare domain. }\end{array}$ \\
\hline [34] & $\checkmark$ & $\checkmark$ & $\begin{array}{l}\text { Medline, Embase, CINAHL, } \\
\text { Cochrane, Scopus, and Web } \\
\text { of Science }\end{array}$ & 19-8-2018 & $\begin{array}{l}\text { Systematic review for } 13 \text { studies to } \\
\text { identify the methods utilized to } \\
\text { assess the users' acceptance of } \\
\text { rehabilitation technologies for adults } \\
\text { with moderate to severe traumatic } \\
\text { brain injury. }\end{array}$ \\
\hline $\begin{array}{l}\text { This } \\
\text { study }\end{array}$ & $\checkmark$ & $\checkmark$ & $\begin{array}{c}\text { PubMed, IEEE Xplore, } \\
\text { Springer, ACM, Science } \\
\text { Direct, and Google Scholar }\end{array}$ & 20-0-2019 & $\begin{array}{l}\text { Systematic review that includes } \\
142 \text { studies for technology acceptance } \\
\text { in healthcare to classify the studies } \\
\text { based on the technology acceptance } \\
\text { models, the studied information } \\
\text { technologies, participants, and } \\
\text { countries of implementation. The } \\
\text { study also aims to identify the } \\
\text { prevailing acceptance models, most } \\
\text { utilized factors, and the most } \\
\text { confirmed relationships to address } \\
\text { the literature gaps and help to build } \\
\text { integrated models for technology } \\
\text { acceptance in the healthcare domain. }\end{array}$ \\
\hline
\end{tabular}

\section{Materials and Methods}

This review is based on the findings from studies published in digital journals and databases to discuss and empirically explore technology acceptance in healthcare. A review of the previous relevant literature is a vital phase of any scientific study [46]. Generally, reviews can simplify and extend the theory development, filling gaps in research, or close areas where a profusion of research exists [47]. A systematic review is helpful to make researchers more familiar with the research topic [48]. Systematic reviews are different from traditional or narrative reviews, since systematic reviews are more rigorous and provide a well-defined approach to review a particular subject area [49].

As presented in Figure 1, the guidelines of the Preferred Reporting Items for Systematic Reviews and Meta-Analysis (PRISMA) have been applied to conduct this review [50,51]. Using the PRISMA helps in demonstrating the flow of information through the different phases of the review [52]. It also depicts the number of articles identified, included, and excluded and the rationale behind the excluded articles. The methods used to identify and collect the relevant studies in this review included different phases: define the inclusion/exclusion criteria, determine the sources and digital databases, specify the search strategies, and analyze the retrieved studies. 


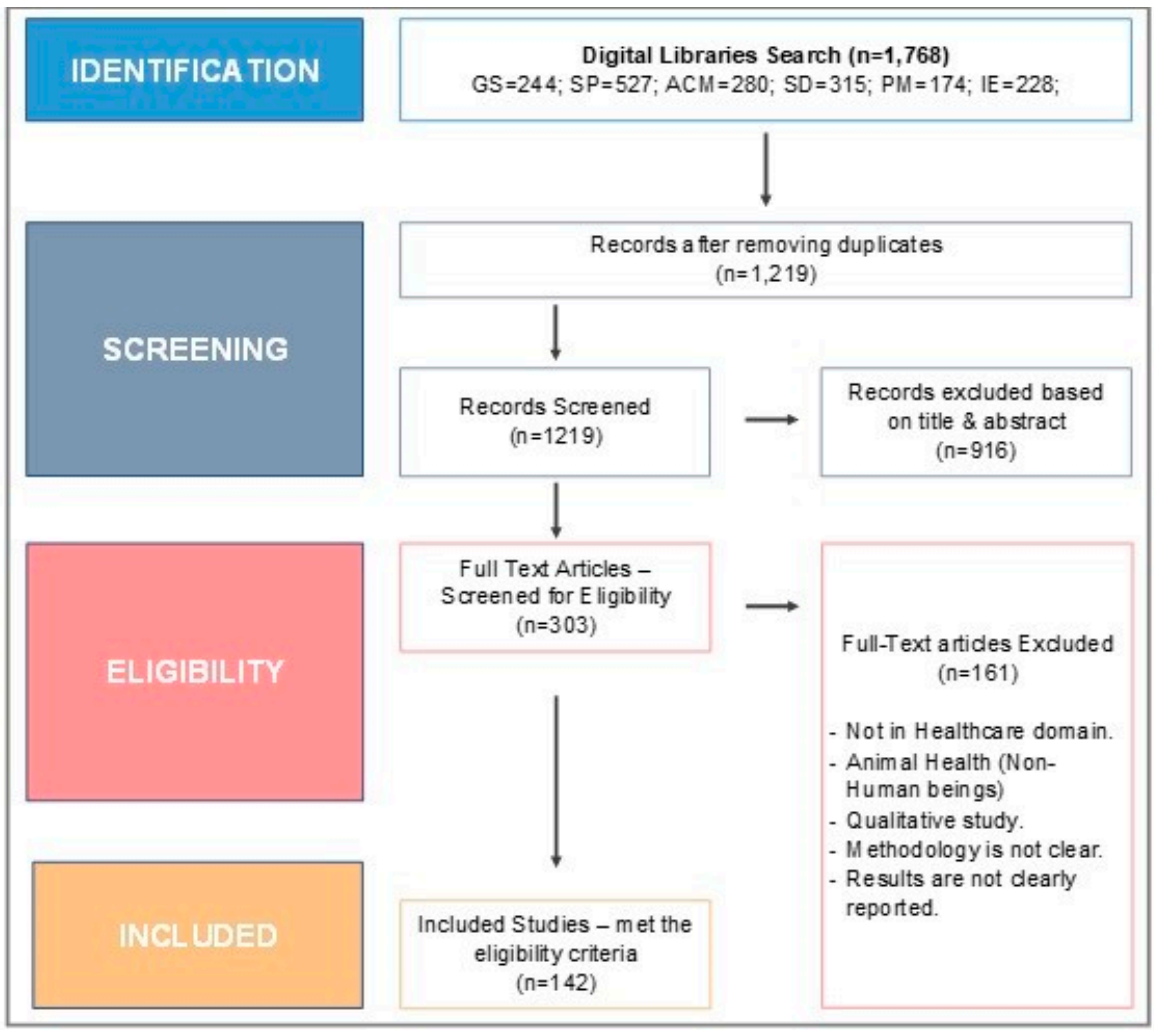

Figure 1. PRISMA flow diagram.

\subsection{Inclusion/Exclusion Criteria}

The inclusion and exclusion criteria are defined to set the selection rules for studies before the analysis phase (see Table 2). The specified criteria are crucial to decide whether the study is valid to be included in the analysis and ensure consistency in the reviewed studies.

Table 2. Inclusion and exclusion criteria.

\begin{tabular}{|c|c|c|}
\hline ID & Inclusion Criteria & Exclusion Criteria \\
\hline 1 & $\begin{array}{l}\text { The objective of the study should be related } \\
\text { to the application of technology acceptance } \\
\text { theories in healthcare. }\end{array}$ & $\begin{array}{l}\text { The study is related to applying technology } \\
\text { acceptance or adoption but not in } \\
\text { healthcare (e.g., banking). }\end{array}$ \\
\hline 2 & $\begin{array}{c}\text { The research model and its related } \\
\text { hypotheses were empirically evaluated. }\end{array}$ & $\begin{array}{l}\text { The research model was evaluated using a } \\
\text { qualitative method or not even evaluated. }\end{array}$ \\
\hline 3 & $\begin{array}{l}\text { The study must be a journal article, } \\
\text { conference paper, book chapter, Ph.D. } \\
\text { dissertation, or master's thesis. }\end{array}$ & $\begin{array}{c}\text { The study is a review, position paper, } \\
\text { editorial, etc. }\end{array}$ \\
\hline 4 & $\begin{array}{l}\text { The study must be published in the } \\
\text { English language. }\end{array}$ & $\begin{array}{c}\text { The study is published in languages other } \\
\text { than English. }\end{array}$ \\
\hline
\end{tabular}

\subsection{Data Sources and Search Strategy}

The studies have been identified by exploring six digital databases, including PubMed, IEEE Xplore, ACM digital library, Springer, Science Direct, and Google Scholar. The selected databases were searched to collect studies that have been published between January 2010 and December 2019 (10 years), where the search was conducted in January 2020. A search strategy was developed using specific search keywords, as presented in Table 3. By following the developed search keywords and strategy, the initial search results showed a total number of 1768 studies, as seen in Figure 1. In that, the inclusion and exclusion criteria were applied, and the refinement stages as per the PRISMA were followed. The 
analysis of the collected studies was carried out by the first and third authors of this study by analyzing each article independently. The differences in analyzing the studies between the two authors were resolved through discussion and further review of the disputed studies. Accordingly, a total number of 142 studies were recognized as valid to be included in the analysis.

Table 3. Summary of search keywords.

\begin{tabular}{cc}
\hline ID & Keywords \\
\hline 1 & ("Technology Acceptance") AND (Healthcare OR Health OR Medical OR Physician \\
OR Nurse OR Patient)
\end{tabular}

\subsection{Data Abstraction and Analysis}

All citations have been downloaded into Mendeley reference manager [53]. The characteristics of the research methodology have been coded to include (i) the studied technology acceptance model, (ii) the included factors in the study, (iii) the confirmed relationships between the factors as hypothesized in the research model (main findings), (iv) types of the studied information technologies, (v) participants, (vi) digital library (database), (vii) year of publication, and (viii) country (direction of research). The filtration process for the studies started by quickly screening the title and abstract. If the study passes this round, the full paper will be obtained and recorded in a different folder for the full and final round of review. The data were extracted through three stages. The first phase determines the theory used to explore the factors impacting specific technology acceptance in healthcare. The second phase categorizes the studies based on the publication year, publication type, and country of implementation. The third stage extracts the studied constructs, understands the developed hypotheses, and analyzes the findings.

A total of 1768 studies were retrieved from the digital libraries, as seen in Figure 1. After the removal of 549 duplicates, 1219 publications were sent out to the screening process. The titles and abstracts were assessed for the 1219 publications. The results of screening confirmed the exclusion of 916 records due to their incompatibility with the inclusion criteria. The full texts of 303 studies were then scanned to ensure their relevance to the subject of this study. The final number was 142 studies, which were found eligible to be analyzed and included in the study (Table A2 in Appendix B).

\subsection{Quality Assessment}

It is crucial to assess the quality of the collected studies [54]. Therefore, a quality assessment checklist was designed to include seven items to evaluate the quality of the eligible research studies $(N=142)$. As seen in Table 4 , the checklist had no intention to criticize the work of any researcher [49]. The designed checklist was conformed to what was suggested in prior research $[49,55,56]$. The checklist is based on a 3-point scale from 0 to 1 , where 0 means "no", 0.5 "partially", and 1 "yes". The results of the quality assessment can be seen in Table A1 in Appendix A. In general, all the included studies have passed the quality assessment and are considered valid to be further analyzed. 
Table 4. Quality assessment checklist.

\begin{tabular}{cc}
\hline Sr. & Question \\
\hline 1 & Does the research have clear aims and objectives? \\
2 & Are the technology acceptance model and its hypotheses well specified? \\
3 & Are the data collection methods appropriately detailed? \\
4 & Does the study explain the reliability and validity of the measures? \\
5 & Are the statistical techniques utilized to analyze the data well clarified? \\
6 & Do the findings add to the literature? \\
7 & Does the study add to the readers' knowledge or understanding? \\
\hline
\end{tabular}

\section{Results}

The results of the review provided a detailed analysis of the recent literature on technology acceptance in healthcare. The comprehensive summary for all the included studies can be found in Table A2 in Appendix B. According to the analyzed 142 studies, the findings of the study can be summarized based on the six research questions.

\subsection{Prevailing Technology Acceptance Models and Theories in the Healthcare Domain}

As mentioned earlier, many technology acceptance models have been discussed in different domains, including healthcare [57]. In Table A2, the authors have classified the studies based on the studied acceptance model. As seen in Figure 2, the TAM, its extensions, and modifications are leading the research of technology acceptance in healthcare $(N=76)$ [58-61]. It was also found that several studies $(N=21)$ have discussed the integration between TAM and other technology acceptance models (e.g., UTAUT, TPB) [62-64]. The analysis also shows that the UTAUT and its extensions were widely employed to explore the user's acceptance of technology in healthcare $(N=26)[65,66]$. Further, the results showed that the number of studies related to the employment of the TPB model is reasonable $(N=12)$.

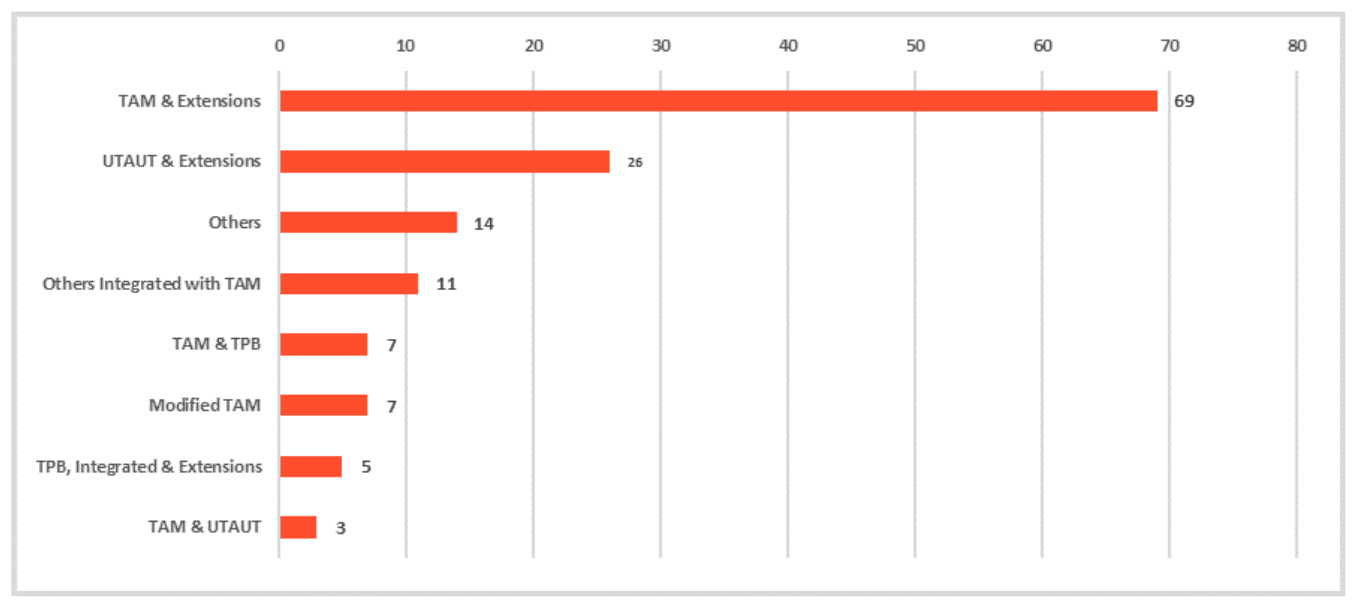

Figure 2. Most studied technology acceptance models.

\subsection{Key Factors Affecting Technology Acceptance in the Healthcare Domain}

For being the key constructs of the TAM, perceived ease of use $(N=98)$ and perceived usefulness $(N=105)$ have been explored and utilized in many studies to assess the acceptance of various technologies in healthcare [60,67-69]. With evidence from 125 different studies, the analysis indicated that behavioral intention to use technology is the most used factor in evaluating the acceptance of different technologies in healthcare (see Figure 3). Although such a result is expected, it is significant to confirm the need for behavioral intention within the theory and practice of technology acceptance. 


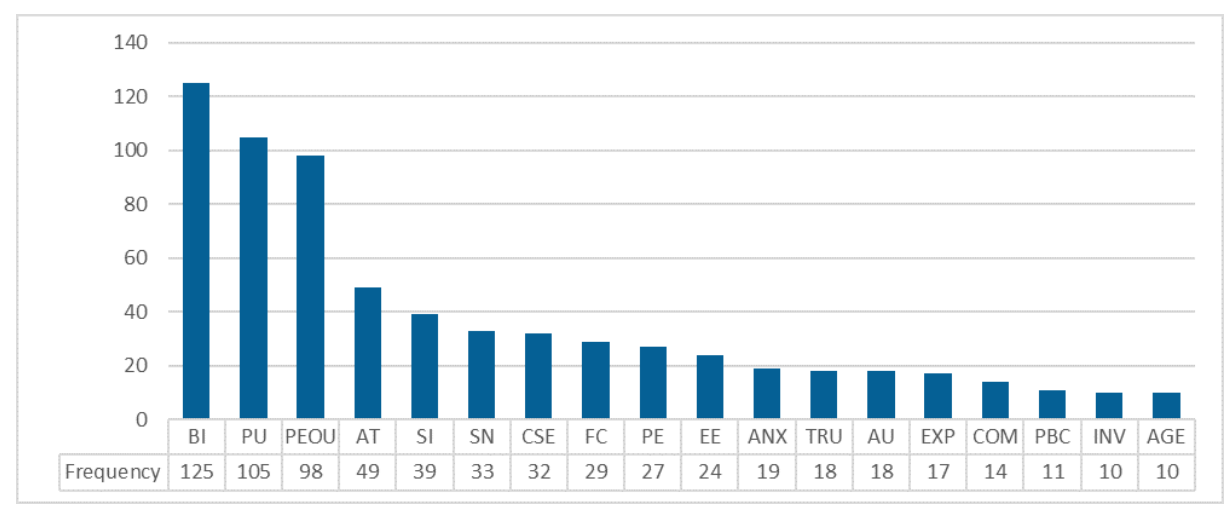

Figure 3. Key factors affecting technology acceptance in healthcare.

Another aspect that needs to be considered is the user's performance and the related expected positive gain that has been investigated extensively, as per the findings in Figure 3. A similar case with the perceived ease of use factor and its equivalent effort expectancy appeared in the analysis for 98 and 24 times, respectively.

Apart from the factors of TAM and UTAUT acceptance models, the results showed that other factors had been extensively utilized to understand the acceptance of technology in healthcare. These factors include anxiety $(N=19)$ and computer self-efficacy $(N=32)$ from the social cognitive theory $[1,19,20]$, innovativeness $(N=10)[70]$, and trust $(N=18)[71]$ as external factors.

\subsection{Main Confirmed Relationships among the Influential Factors}

The classification analysis in this study included an investigation for the most confirmed hypotheses as per the recent literature. Those hypotheses were developed as a part of the proposed models within various studies, confirmed by several scholars, and considered significant for technology acceptance in the healthcare domain. It is crucial to understand those common hypotheses to let researchers understand the potential correlation between the factors within the model. Similar to the determination of key factors, understanding the potential significant correlations can help to develop and enhance acceptance theories based on the findings of previous studies [72].

As seen in Figure 4, the most confirmed hypotheses were the significant correlation between the "perceived usefulness" and the behavioral intention to use a specific technology $(N=61)$ and between the "perceived ease of use" and "perceived usefulness" $(N=59)$. In general, the results confirmed the key relationships as hypothesized in TAM and UTAUT models. On the other hand, we cannot disregard the extensive impact of social influence, trust, anxiety, innovativeness, and computer self-efficacy factors on technology acceptance in healthcare. In other words, the frequency in Figure 4 presents the number of studies that have confirmed the significance of each hypothesis.

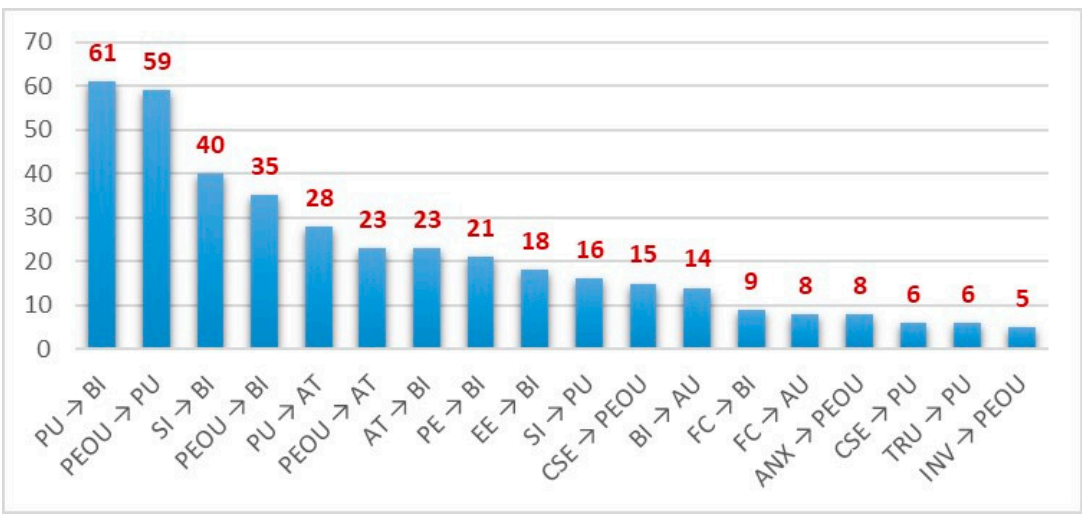

Figure 4. The most confirmed hypotheses in the reviewed literature. 


\subsection{Main Information Technologies and Their Relationships with Countries and Participants}

Figure 5 presents the distribution of the studied information technologies in the reviewed studies. As suggested by Rahimi et al. [6], the categorization of information technologies was performed based on the Medical Subject Headings (MeSH) thesaurus [73]. With more than $48 \%(N=69)$, it is clear that prior research is mainly dominated by five main categories, including telemedicine solutions, HIT systems in general, cloud computing applications, mobile applications, and electronic health records (e.g., health information solutions and electronic medical records). By having a quick look at the analysis in Table 5, it seems that the classification of technologies across the countries is equally distributed, with a slight notable difference in telemedicine and cloud computing. Telemedicine was mainly studied in Taiwan and the USA, while cloud computing was primarily studied in Taiwan.

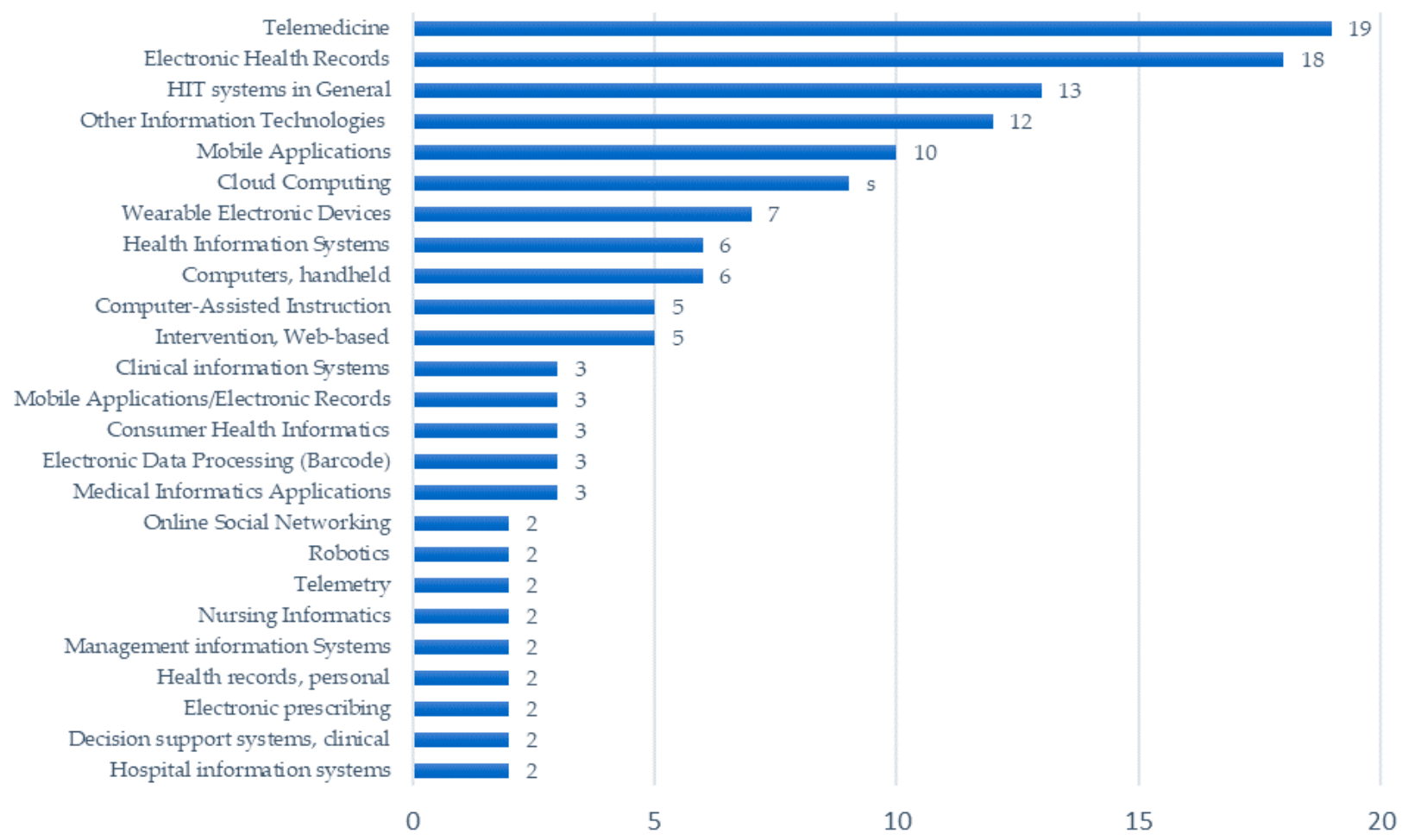

Figure 5. Distribution of studies in terms of technology type.

Table 5. Technology types and directions of countries.

\begin{tabular}{ccc}
\hline Technology & Frequency & Countries \\
\hline Telemedicine & 19 & $\begin{array}{c}\text { Taiwan (4), USA (3), Germany (2), Malaysia (2), South Korea (2), } \\
\text { Spain, India, UK, Slovenia, China, Georgia }\end{array}$ \\
\hline Electronic Health Records & 18 & $\begin{array}{c}\text { USA (3), Austria (2), Iran (2), Jordan, India, Turkey, Taiwan, Spain, } \\
\text { Saudi Arabia, Singapore, France, Canada, Armenia, Australia }\end{array}$ \\
\hline HIT Systems in General & 13 & $\begin{array}{c}\text { Morocco (2), South Korea (2), UK and UAE (2), Nigeria, Australia, } \\
\text { Thailand, Canada, North Macedonia, Turkey, Germany }\end{array}$ \\
\hline Mobile Applications & 10 & Germany (2), Taiwan (2), China (2), Malawi, Singapore, Spain, UK \\
\hline Cloud Computing & 9 & Taiwan (7), Nigeria, one study conducted in: Malaysia, Pakistan, \\
and Saudi Arabia
\end{tabular}


Table 5. Cont

\begin{tabular}{|c|c|c|}
\hline Technology & Frequency & Countries \\
\hline Wearable Electronic Devices & 7 & Germany (2), Taiwan (2), China (2), USA \\
\hline Computers, Handheld & 6 & $\begin{array}{l}\text { USA (2), China, Turkey, South Korea, one study conducted in: } \\
\text { UAE and UK }\end{array}$ \\
\hline Health Information Systems & 6 & Taiwan (3), Canada, Indonesia, Malaysia \\
\hline Intervention, Web-Based & 5 & Taiwan (2), Belgium, Malaysia, Thailand \\
\hline Computer-Assisted Instruction & 5 & Hong Kong (2), Taiwan, Iran, Indonesia \\
\hline Medical Informatics Applications & 3 & USA (3) \\
\hline Electronic Data Processing (Barcode) & 3 & USA (2), Iran \\
\hline Consumer Health Informatics & 3 & USA, Malaysia, Indonesia \\
\hline Mobile Applications/Electronic Records & 3 & Taiwan (2), South Korea \\
\hline Clinical Information Systems & 3 & Malaysia (2), France \\
\hline Hospital Information Systems & 2 & Iran, Indonesia \\
\hline Decision Support Systems, Clinical & 2 & Taiwan, Iran \\
\hline Electronic Prescribing & 2 & USA, Pakistan \\
\hline Health Records, Personal & 2 & USA, China \\
\hline Management Information Systems & 2 & India, one study conducted in: USA and Taiwan \\
\hline Nursing Informatics & 2 & Taiwan (2) \\
\hline Telemetry & 2 & Spain (2) \\
\hline Robotics & 2 & USA, Finland \\
\hline Online Social Networking & 2 & USA, Uganda \\
\hline $\begin{array}{l}\text { Other Information Technologies (One } \\
\text { Study Each) }\end{array}$ & 12 & $\begin{array}{c}\text { Taiwan (2), USA (2), Iran, Jordan, Spain, Saudi Arabia, Turkey, } \\
\text { Malaysia, Singapore, UK }\end{array}$ \\
\hline
\end{tabular}

Figure 6 presents the distribution of studies according to the participants (user groups). With almost $56 \%$ of the total participants, physicians $(N=30)$, nurses $(N=24)$, and healthcare professionals in general $(N=26)$ attracted the attention of scholars to understand their technology acceptance. In terms of technology type and participants, we observed that the focus is scattered with little attention to study the acceptance of electronic health records by the same leading user groups (see Table 6). Additionally, there are efforts to understand the acceptance of patients and the general population as non-healthcare workers for various technologies, including telemedicine, mobile applications, cloud computing, and wearable electronic devices.

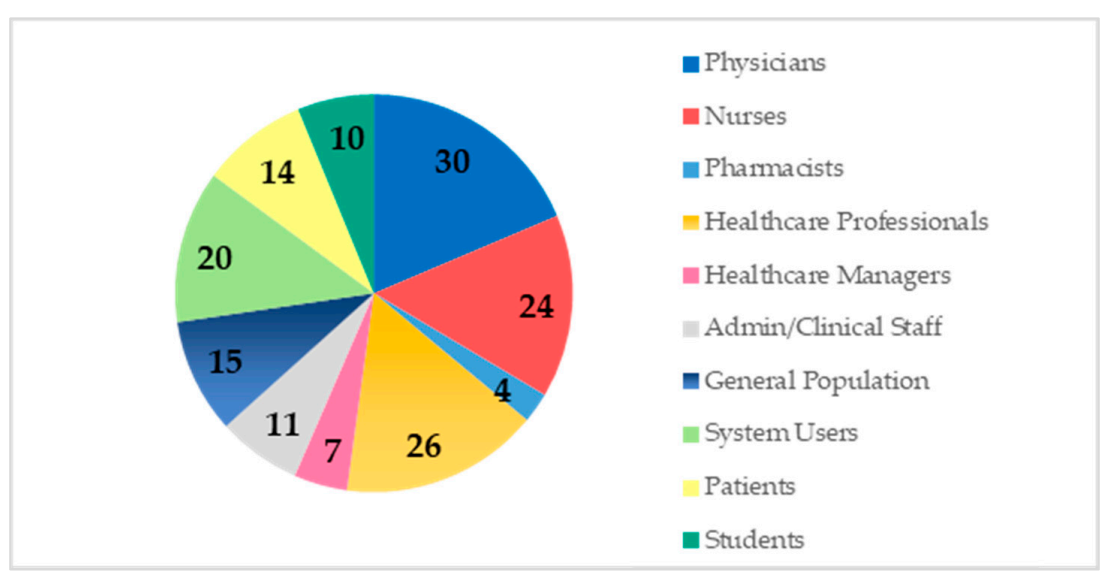

Figure 6. Distribution of studies in terms of participants. 
Table 6. Technology types and participants' groups.

\begin{tabular}{|c|c|c|c|c|c|c|c|c|c|c|}
\hline \multirow[b]{2}{*}{ Technology } & \multicolumn{10}{|c|}{ Participant Groups } \\
\hline & 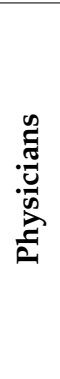 & 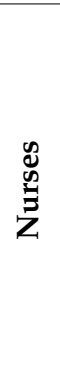 & 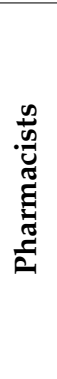 & 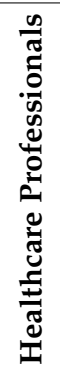 & 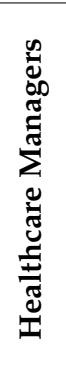 & 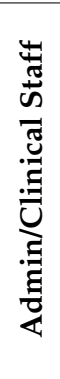 & 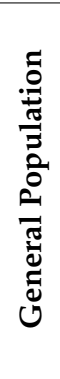 & 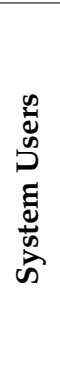 & 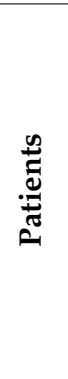 & 苞 \\
\hline Telemedicine & 4 & 1 & & 5 & & 1 & 4 & 1 & 4 & \\
\hline Electronic Health Records & 7 & 5 & & 2 & 1 & 4 & 1 & 1 & & 1 \\
\hline HIT Systems in General & 2 & 4 & & 1 & 2 & 2 & & 1 & & 1 \\
\hline Mobile Applications & & & & 2 & & & 4 & 3 & 1 & 1 \\
\hline Cloud Computing & & & 1 & 3 & & & 1 & 1 & 3 & \\
\hline Wearable Electronic Devices & & & & 1 & & & 3 & 1 & 2 & \\
\hline Handheld Computers & 3 & & & 2 & & 1 & & & 1 & 1 \\
\hline Health Information Systems & & 3 & & 1 & 1 & 2 & & 1 & & \\
\hline Web-Based Systems (Intervention) & & & & 2 & & & 1 & 1 & 1 & \\
\hline Computer-Assisted Instruction & 1 & 1 & & & & & & & & 3 \\
\hline Medical Informatics Applications & & 1 & & 1 & 1 & & & & & \\
\hline Electronic Data Processing (Barcode) & & 1 & 1 & & & & & 1 & & \\
\hline Consumer Health Informatics & & & & & & & & 3 & & \\
\hline Mobile Applications/Electronic Records & 1 & 1 & & 1 & & & & & & \\
\hline Clinical Information Systems & 2 & & & & & & & 3 & & \\
\hline Hospital Information systems & 1 & & & & & 1 & & 1 & & \\
\hline Decision Support Systems & 2 & & & & & & & & & \\
\hline Electronic Prescribing & 2 & & & & & & & & & \\
\hline Health Records (Personal) & & & & & & & 1 & 1 & & \\
\hline Management Information Systems & 2 & 1 & 1 & & & & & & & \\
\hline Nursing Informatics & & 2 & & & & & & & & \\
\hline Telemetry & 2 & 2 & & & & & & & & \\
\hline Robotics & & & & 2 & & & & & 1 & \\
\hline Online Social Networking & & 1 & & & & & & & & 1 \\
\hline Other Technologies & 1 & 1 & 1 & 3 & 2 & & & 1 & 1 & 2 \\
\hline Total & 30 & 24 & 4 & 26 & 7 & 11 & 15 & 20 & 14 & 10 \\
\hline
\end{tabular}

\subsection{Distribution of Studies across Regions and Countries}

This review also determined the origin country and the region for each analyzed study. As per Figure 7, the majority of publications were conducted in Asia $(N=76)$, with $53.5 \%$ of the whole analyzed studies. Taiwan recorded $20.27 \%(N=30)$ of the entire analyzed studies, as seen in Table 7. Further, the USA as a first runner-up is doing well, with 22 empirical studies $(14.86 \%)$ to assess technology acceptance in healthcare. As shown in Figure 8 , the geographic heat map indicates that there are no publications conducted in the Central and South American regions. The rest of the statistics related to country and region are illustrated in Table 7 and Figures 7 and 8. 


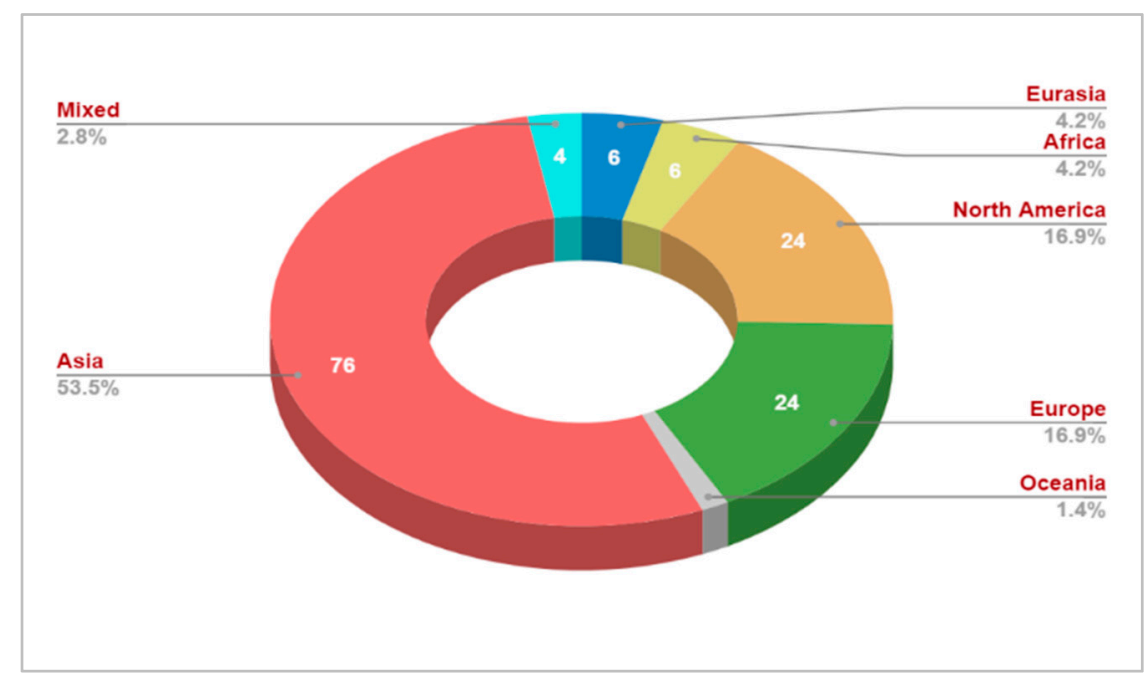

Figure 7. Publications statistics per region. Mixed: conducted in two different regions.

Table 7. Top countries by publication frequency.

\begin{tabular}{cccc}
\hline ID & Country & Frequency & Percentage (\%) \\
\hline 1 & China & 7 & 4.73 \\
2 & Germany & 7 & 4.73 \\
3 & Iran & 7 & 4.73 \\
4 & Malaysia & 9 & 6.08 \\
5 & South Korea & 6 & 4.05 \\
6 & Spain & 6 & 4.05 \\
7 & Taiwan & 30 & 20.27 \\
8 & United Kingdom & 6 & 4.05 \\
9 & USA & 22 & 14.86 \\
\hline
\end{tabular}

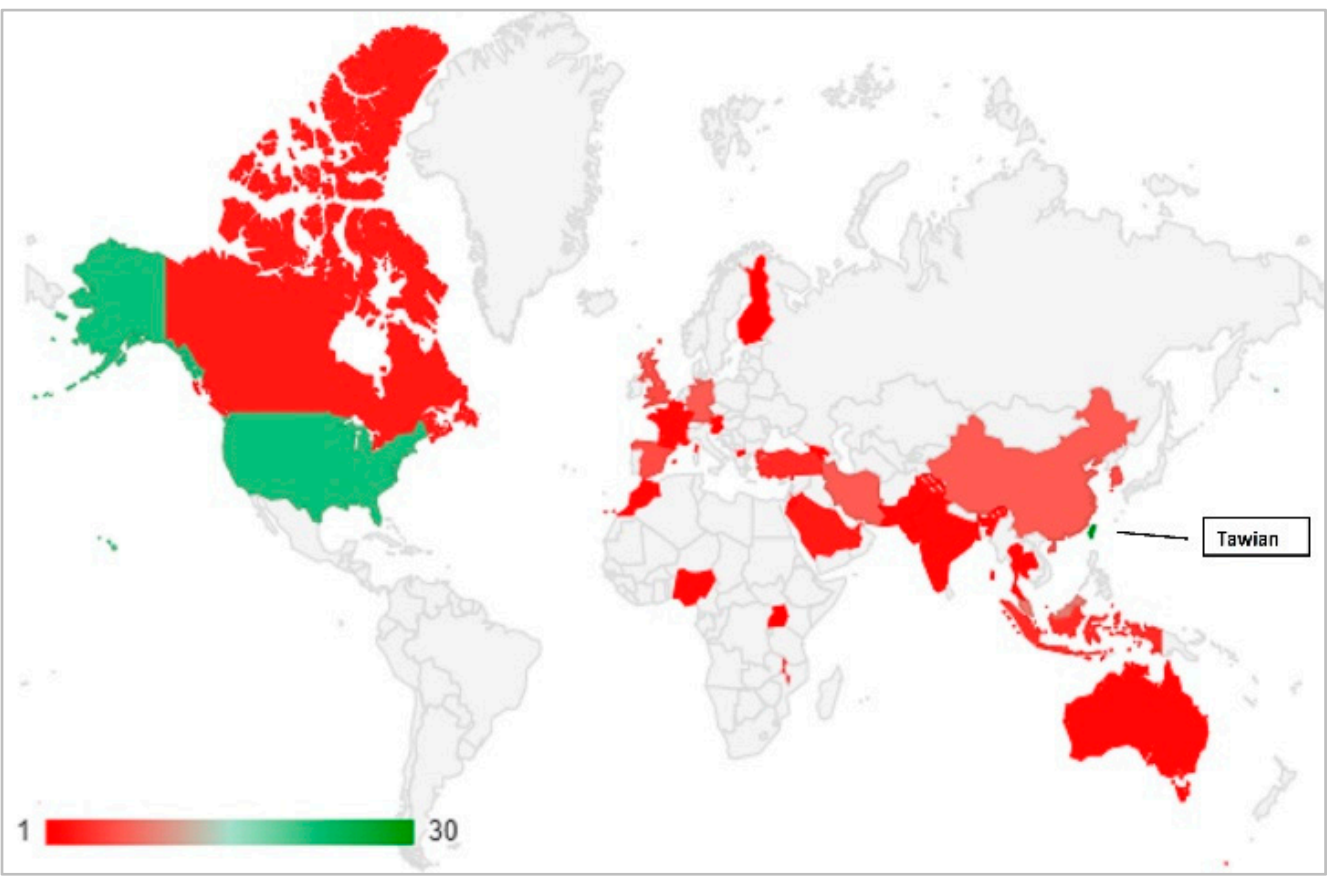

Figure 8. Geographic chart for the studies included in this review. 


\subsection{Progress of Technology Acceptance Studies in Healthcare}

The analyzed studies in the inspected period were categorized according to the year of publication, as presented in Figure 9. The studies are reflected through more or less constant frequency in the last decade, with peaks in 2013, 2015, and 2016. There is a remarkable drop in the number of studies from 2017, which can maximize the gap in the technology acceptance literature, especially with the ongoing boom in information technologies.

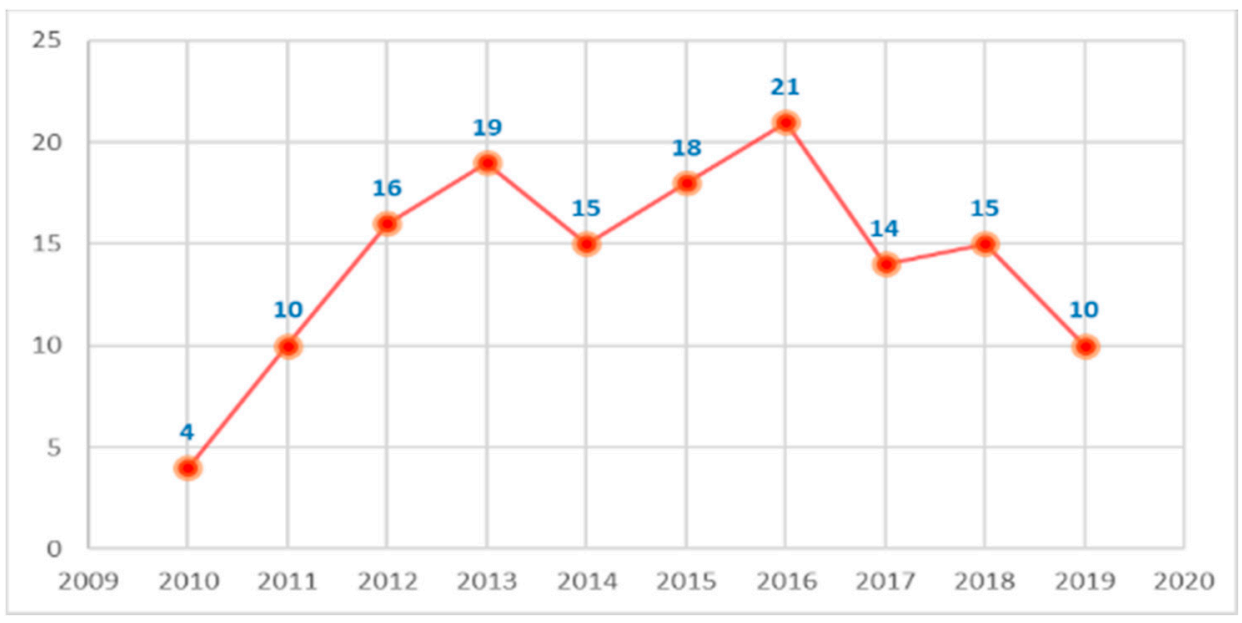

Figure 9. Frequency of studies per year.

\section{Discussion}

The results of this review are believed to add a thorough understanding of the literature on technology acceptance in healthcare. The fundamental goal of this study was to review the empirical studies and analyze the results to understand the research situation of technology acceptance in the healthcare sector. This review covered the studies conducted in the recent decade to explore the acceptance of different technologies using different acceptance theories, various factors, and different healthcare organizations or settings. Figure 10 represents the mind map for the results summary. Concerning the study characteristics, the analysis classified the studies according to the studied model to address the prevailing technology acceptance models in the healthcare domain. The TAM, its extensions, and modifications are leading the research of technology acceptance in healthcare. It was also found that several studies have discussed integrated models. In general, the main aim of the integration in those studies was to improve the explanatory power of the TAM model. These results align with what was proposed by [47] regarding the power of TAM in investigating the user's acceptance of technology in general. Moreover, the UTAUT and its extensions were widely employed to explore the user's acceptance of several healthcare technologies. This observation is compatible with the conclusions of prior research $[28,29]$. Additionally, the results showed that the number of studies, including the TPB model, is reasonable. These findings confirm the importance of studying various models as performed by $[18,31]$, to better understand technology acceptance and facilitate building more unified models [74].

This study also explored the key factors that were extensively employed in the recent literature to understand the acceptance of various healthcare technologies. The results showed that behavioral intention was utilized 125 times in the reviewed studies. This finding is significant to confirm the need for behavioral intention within the theory and practice of technology acceptance. Consequently, providers of information technologies and healthcare organizations have to focus on the users' intention to enhance the level of acceptance, regardless of whether they are professional staff or patients. Perceived ease of use and perceived usefulness have been explored in numerous studies to assess the acceptance of various technologies in healthcare [60,67-69]. These two factors are the core of the TAM. Other studies have confirmed that these constructs could explain 
about $40 \%$ of users' acceptance and intention to use specific technologies [33] in various domains, including healthcare $[30,75,76]$. Instead, the UTAUT was found to extend the explanatory power by $20 \%$ to $30 \%$ more than TAM regarding user's behavior intention [31]. The capability of UTAUT to explain the intention to use specific technology can reach $70 \%$, especially with the injection of facilitating conditions and social influence factors, with age, gender, experience, and voluntariness as moderators [33]. The TAM, UTAUT, and their constructs are robust theories to understand the acceptance of various technologies through different users.

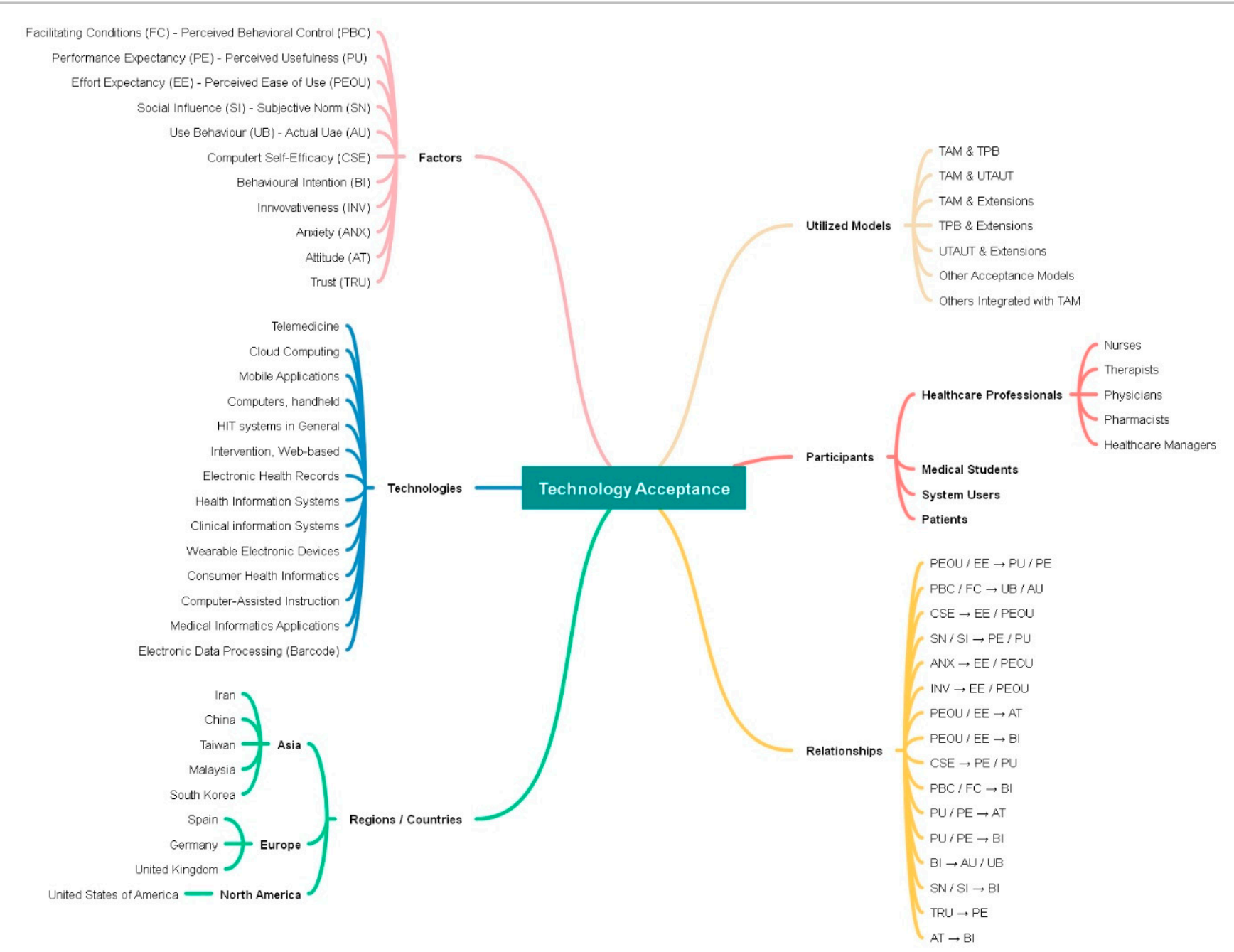

Figure 10. Mind map for the results summary.

The analysis revealed that the user's performance and its related expected positive gain had been investigated extensively. Those expected positive performance gains are linked with the perceived usefulness factor and its equivalent performance expectancy $[9,18,31]$. This is also applied to the perceived ease of use and its identical factor, effort expectancy. These results indicate that it is mandatory to extend the levels of convenience in information technologies and make them more user friendly. In addition, the clear presence of the facilitating conditions factor and its equivalent factors "compatibility" and "perceived behavioral control" confirm the users' need for support and motivation to accept and use information technologies in healthcare. Additionally, scholars have not missed the importance of exploring innovativeness, computer self-efficacy, trust, and anxiety factors. A user will not use technology if he/she does not trust the technology or its creator. Similarly, 
it sounds reasonable to address users' innovativeness and confidence to use information technology without fear of making mistakes.

With a link to the extensively studied factors, the analysis investigated the most confirmed hypotheses in the recent literature. It is crucial to understand those common hypotheses to let researchers understand the potential correlations between the factors within a specific model. The determination of confirmed hypotheses is essential to understand the possible significant correlations between constructs and assist researchers in developing or enhancing acceptance theories based on the findings of other scholars. The recognition of the factors and their confirmed correlations can provide a better view for decision makers and help them determine the technology's strengths and weaknesses, enhancing its level of acceptance [77].

The results found that perceived usefulness and ease of use encourage behavioral intention in healthcare. Such a result suggests that users' behavioral intention is mainly influenced by their spent efforts to use a specific technology and their belief regarding the expected benefits from using that technology $[9,78]$. Additionally, the results exposed that attitude toward using technology in healthcare is widely influenced by the expected performance results and effort expectancy. This implies that the end-users have a positive attitude regarding using a specific technology to improve their work efficiency [31,79]. It is essential to implement user-friendly solutions in healthcare to expand the positive attitude toward technology adoption [31,61]. The relationship between social influence and both behavioral intention and perceived usefulness was extensively confirmed. This correlation suggests that users' behavioral intention to use technology is significantly influenced by their social groups and beliefs regarding the expected enhancement in performance.

Regarding the studied information technologies, the analysis classified them by type and directions of countries to explore the booming topics in specific regions and countries. This can signify a lack or plethora in the literature regarding a particular technology or country. The classification of technologies can enable scholars to have a look for other technology solutions in healthcare. The results showed that telemedicine and electronic health records were the most studied technologies in general. This observation indicates that there is still room to explore the acceptance of these technologies in different countries and settings, especially that there is no specific country to lead the research.

In general, the results indicated that specific technologies dominate the literature, but this conclusion is deceptive, since the literature is scattered in terms of technology use per country. There is still a gap in discovering the factors that impact the acceptance of many information technology solutions in healthcare. Those solutions can fail due to the uncertainty of adoption enablers, barriers, and users' acceptance. It is, therefore, recommended to conduct more research on the technologies that are not covered or neglected, such as picture archiving and communication systems (PACs) [9] and robotics [80].

Concerning the distribution of the participants across the technologies type, the results indicated that prior research focused on the healthcare workers (e.g., physicians, nurses, and healthcare professionals) to study their acceptance of different technologies. This result can be misleading when the technology type is added. The reviewed studies could not confirm a clear focus except for the electronic health records by the aforementioned leading participants, which remains a research gap. Hence, further research may consider this prospective gap and try to discover the acceptance of other technologies by various user groups. Moreover, the literature witnessed extensive work to explore the acceptance of telemedicine, mobile applications, cloud computing, and wearable electronic devices by patients and the general population as non-healthcare workers. This finding can be explained by the need to understand the influence of innovativeness, trust, and anxiety on regular users' acceptance. For instance, a user needs to be innovative to try a new smartwatch or mobile application without fear of making mistakes and trust that the technology will not make his/her data public or breach the confidentiality terms.

Addressing the origin of publications can help to recognize a research gap in a specific country or region within particular subject areas. It helps to improve the research directions 
and create extra motivations for researchers. The results showed no publications regarding technology acceptance in healthcare within the Central and South American regions. This provides a research gap that is required to be filled by the researchers in these regions. This result can also indicate that technology implementation in the healthcare domain is rare in these two regions. By looking into the developing regions, Arab and African countries need to expand the research in technology acceptance. Despite the advanced healthcare services and the increasing use of information technologies across many Arab countries, the lack of technology acceptance research exists, specifically in the healthcare domain.

Taiwan recorded $20.27 \%$ of the analyzed studies, which makes up almost $40 \%$ of the total number of studies in Asia. This might be an outcome for the well-established healthcare systems in Taiwan [81]. In contrast, China and South Korea's results are shocking compared to the boom in information technologies in these two countries. These results could be a gap that referred to the language with no assurance, especially that many scholars are publishing their research using their mother-tongue languages. Therefore, more research studies can be conducted to understand the enablers and barriers to adopting various healthcare technologies in China and South Korea.

Regarding the years of publication, the results indicated a fluctuation in the number of studies per year. The number of research articles has increased from 4 studies in 2010 to an average of 17 studies from 2012 to 2018 . The hike could refer to the increased focus on telemedicine, electronic health records, cloud computing, and mobile applications. With 27 studies conducted in Taiwan and 17 in the USA, both countries have significantly encouraged the observed increase. Finally, the remarkable drop in the number of studies from 2017 to 2019 does not support technology acceptance literature. The current need to adopt new technologies and improve healthcare services opens the door for more studies to explain technology acceptance. It is expected that the number of studies will increase due to the outbreak of COVID-19 that was identified in December 2019 in China and has resulted in the deaths of thousands of human beings worldwide [82,83].

\section{Conclusions}

This study aimed to systematically provide an overview of the studies published on technology acceptance in healthcare. The study provided a classification analysis that includes the studied technology acceptance models, the influential factors, the confirmed relationships among those factors, the types of the studied information technologies, participants, year of publication, and countries (direction of research). Following the PRISMA guidelines, 1768 published studies were reviewed, and 142 studies were found to be valid and included in the statistical analysis. According to the findings, it is clear that TAM and UTAUT are the prevailing technology acceptance models. Additionally, the analysis found that the constructs of TAM and UTAUT were the most utilized factors to understand the acceptance of technology in healthcare. Moreover, other factors were extensively studied including, computer anxiety, computer self-efficacy, innovativeness, and trust. Overall, room is still available to integrate various technology acceptance models or add other factors to the current models to produce more robust and valid acceptance models.

On the other hand, some technology solutions were found to be dominant, including electronic health records, telemedicine, and mobile applications. In general, the results were scattered in terms of the research directions (technology country). Healthcare workers (i.e., physicians, nurses, and healthcare professionals) were the main focus of the reviewed studies. Patients' technology acceptance was only discussed in around 10\% of the reviewed studies. In addition, the reviewed studies were mainly conducted in Taiwan and the USA, with minimum research articles in Arab and African countries.

\subsection{Theoretical Contributions}

As per the conducted classification analysis, the study provided multiple contributions to technology acceptance models and theories, especially in healthcare. This systematic 
review is believed to add a significant contribution to the existing literature for several reasons. First, it analyzed all the technology acceptance models instead of focusing on one model or theory (e.g., TAM). Second, this study included only the empirically evaluated acceptance models, their extensions, and integrations. Third, the study reviewed different information technologies instead of considering only one technology (e.g., electronic medical records). Fourth, studies with different settings and types of users were included in the review. Other healthcare professionals such as nurses, pharmacists, and clinical technicians are using the information technologies and playing a critical role in the success of those technologies. Fifth, the considered studies in the review were published in the recent decade (2010-2019), which provides a fresh overview of the literature.

\subsection{Practical Implications}

The study provides various practical implications for the healthcare domain. First, this review differs from the other reviews by including various technology acceptance models, various technologies, and various users. This diversity is valuable for other researchers and decision makers in different research areas, countries, and settings. For instance, virtual clinics can have great potential through telemedicine, cloud computing solutions, and mobile applications. Decision makers need to provide the necessary support for implementing these solutions to help physicians and healthcare professionals in providing many healthcare services (e.g., consultation, follow-up) without meeting the patient, especially in rural areas.

Second, the review shows a gap in the new technology trends in the healthcare sector. The decision makers and IT corporations should employ Internet of Medical Things (IoMT) and virtual reality (VR) solutions. IoMT can help to digitize the process, develop resource allocation, and provide real-time data to drive decisions. Virtual reality solutions can help to train resident physicians and young nurses to feel integrated with situations they may face in reality. Additionally, such augmented solutions can enable the physicians to access the patients' reports without leaving their current location, and using hands-free mode (voice commands).

Third, we believe that the results would assist policy makers in reviewing the current regulations and policies concerning data confidentiality and privacy. Additionally, these regulations should be announced and published. End-users need to be educated and aware of their roles and responsibilities to enhance their acceptance by improving the levels of trust and anxiety.

Fourth, information technology corporations (system analysts and developers) and healthcare organizations can utilize the findings related to the influential factors as a type of lessons learned. Consequently, this review can help to improve the currently implemented solutions and consider enhancements in future technology to be more user-friendly and innovative. Using information technology solutions with fewer efforts can encourage end-users to gain the maximum benefits without fear of making mistakes.

Fifth, the review addressed gaps in the technology acceptance literature by considering the regions of implementation. It has been observed that inadequate attention is paid to implementing cloud computing, telemedicine, and medical informatics applications in developing countries. Therefore, IT corporations need to concentrate on Arab and African countries, as there is potential to implement those new information technologies within the healthcare sector in these countries.

\subsection{Limitations and Future Work}

This systematic review was limited to particular digital libraries and databases to collect the research studies (i.e., PubMed, IEEE Xplore, Springer, ACM, Science Direct, and Google Scholar). Therefore, these digital libraries might not provide a complete picture for all empirical studies published on technology acceptance in healthcare. Future research may extend this review by including studies from other digital libraries, such as CINAHL, 
Cochrane, Scopus, Sage, and Web of Science. Additionally, this review has covered only empirical quantitative studies. Further reviews might consider qualitative studies.

Author Contributions: Conceptualization, A.A.A., M.A.-E. and K.S.; methodology, A.A.A. and M.A.-E.; validation, A.A.A. and M.A.-E.; formal analysis, A.A.A.; investigation, A.A.A.; resources, A.A.A.; writing - original draft preparation, A.A.A.; writing—review and editing, M.A.-E. and K.S.; supervision, M.A.-E. and K.S.; project administration, M.A.-E. and K.S. All authors have read and agreed to the published version of the manuscript.

Funding: This research received no external funding.

Institutional Review Board Statement: Not applicable.

Informed Consent Statement: Not applicable.

Data Availability Statement: The data presented in this study are available on request from the first author.

Conflicts of Interest: The authors declare no conflict of interest. 


\section{Appendix A}

Table A1. Quality assessment results.

\begin{tabular}{|c|c|c|c|c|c|c|c|c|c|c|c|c|c|c|c|c|c|c|c|}
\hline Study & Q1 & Q2 & Q3 & Q4 & Q5 & Q6 & Q7 & Total & Percentage & Study & Q1 & Q2 & Q3 & Q4 & Q5 & Q6 & Q7 & Total & Percentage \\
\hline S1 & 1 & 1 & 0.5 & 1 & 0.5 & 0.5 & 1 & 5.5 & $78.6 \%$ & S72 & 1 & 1 & 0.5 & 1 & 0.5 & 0.5 & 1 & 5.5 & $78.6 \%$ \\
\hline S2 & 1 & 1 & 0.5 & 1 & 0.5 & 0.5 & 1 & 5.5 & $78.6 \%$ & S73 & 1 & 1 & 0.5 & 0.5 & 0.5 & 1 & 1 & 5.5 & $78.6 \%$ \\
\hline S3 & 1 & 1 & 0.5 & 0.5 & 0.5 & 1 & 1 & 5.5 & $78.6 \%$ & S74 & 1 & 1 & 1 & 1 & 1 & 0.5 & 0.5 & 6 & $85.7 \%$ \\
\hline S5 & 1 & 1 & 0.5 & 1 & 0.5 & 0.5 & 0.5 & 5 & $71.4 \%$ & S76 & 1 & 1 & 0.5 & 1 & 0.5 & 1 & 1 & 6 & $85.7 \%$ \\
\hline S6 & 1 & 1 & 0.5 & 1 & 0.5 & 1 & 1 & 6 & $85.7 \%$ & S77 & 1 & 1 & 0.5 & 1 & 1 & 0.5 & 0.5 & 5.5 & $78.6 \%$ \\
\hline S7 & 1 & 1 & 0.5 & 1 & 1 & 0.5 & 0.5 & 5.5 & $78.6 \%$ & $\mathrm{~S} 78$ & 1 & 1 & 0.5 & 0.5 & 1 & 0.5 & 0.5 & 5 & $71.4 \%$ \\
\hline S8 & 1 & 1 & 0.5 & 0.5 & 1 & 0.5 & 0.5 & 5 & $71.4 \%$ & S79 & 1 & 1 & 0.5 & 1 & 0.5 & 0.5 & 0.5 & 5 & $71.4 \%$ \\
\hline S10 & 1 & 1 & 1 & 1 & 1 & 0.5 & 0.5 & 6 & $85.7 \%$ & S81 & 1 & 1 & 1 & 0.5 & 0.5 & 0.5 & 0.5 & 5 & $71.4 \%$ \\
\hline $\mathrm{S} 11$ & 1 & 1 & 1 & 0.5 & 0.5 & 0.5 & 0.5 & 5 & $71.4 \%$ & S82 & 1 & 1 & 0.5 & 0.5 & 0.5 & 0.5 & 0.5 & 4.5 & $64.3 \%$ \\
\hline $\mathrm{S} 12$ & 1 & 1 & 0.5 & 0.5 & 0.5 & 0.5 & 0.5 & 4.5 & $64.3 \%$ & S83 & 1 & 1 & 0.5 & 1 & 0.5 & 0.5 & 0.5 & 5 & $71.4 \%$ \\
\hline S13 & 1 & 1 & 0.5 & 1 & 0.5 & 1 & 0.5 & 5.5 & $78.6 \%$ & S84 & 1 & 1 & 0.5 & 1 & 0.5 & 0.5 & 0.5 & 5 & $71.4 \%$ \\
\hline S14 & 1 & 1 & 0.5 & 1 & 0.5 & 0.5 & 0.5 & 5 & $71.4 \%$ & S85 & 1 & 1 & 0.5 & 1 & 0.5 & 0.5 & 1 & 5.5 & $78.6 \%$ \\
\hline S15 & 1 & 1 & 0.5 & 0 & 0.5 & 1 & 1 & 5 & $71.4 \%$ & S86 & 1 & 1 & 0.5 & 1 & 0.5 & 0.5 & 1 & 5.5 & $78.6 \%$ \\
\hline S16 & 1 & 1 & 0.5 & 1 & 0.5 & 0.5 & 1 & 5.5 & $78.6 \%$ & S87 & 1 & 1 & 0.5 & 0.5 & 0.5 & 1 & 1 & 5.5 & $78.6 \%$ \\
\hline S17 & 1 & 1 & 0.5 & 1 & 1 & 1 & 1 & 6.5 & $92.9 \%$ & S88 & 1 & 1 & 1 & 1 & 1 & 0.5 & 0.5 & 6 & $85.7 \%$ \\
\hline S18 & 1 & 1 & 1 & 1 & 1 & 0.5 & 0.5 & 6 & $85.7 \%$ & S89 & 1 & 1 & 0.5 & 0.5 & 0.5 & 0.5 & 0.5 & 4.5 & $64.3 \%$ \\
\hline S20 & 1 & 1 & 0.5 & 1 & 0.5 & 1 & 1 & 6 & $85.7 \%$ & S91 & 1 & 1 & 0.5 & 1 & 1 & 0.5 & 0.5 & 5.5 & $78.6 \%$ \\
\hline $\mathrm{S} 21$ & 1 & 1 & 0.5 & 1 & 1 & 0.5 & 0.5 & 5.5 & $78.6 \%$ & S92 & 1 & 1 & 1 & 1 & 1 & 0.5 & 1 & 6.5 & $92.9 \%$ \\
\hline $\mathrm{S} 22$ & 1 & 1 & 0.5 & 0.5 & 1 & 0.5 & 0.5 & 5 & $71.4 \%$ & $\mathrm{~S} 93$ & 1 & 1 & 0.5 & 1 & 0.5 & 0.5 & 0.5 & 5 & $71.4 \%$ \\
\hline $\mathrm{S} 23$ & 1 & 1 & 0.5 & 1 & 0.5 & 0.5 & 0.5 & 5 & $71.4 \%$ & S94 & 1 & 1 & 1 & 1 & 1 & 0.5 & 0.5 & 6 & $85.7 \%$ \\
\hline S24 & 1 & 1 & 1 & 1 & 1 & 0.5 & 0.5 & 6 & $85.7 \%$ & S95 & 1 & 1 & 1 & 0.5 & 0.5 & 0.5 & 0.5 & 5 & $71.4 \%$ \\
\hline $\mathrm{S} 25$ & 1 & 1 & 1 & 0.5 & 0.5 & 0.5 & 0.5 & 5 & $71.4 \%$ & S96 & 1 & 1 & 0.5 & 0.5 & 0.5 & 0.5 & 0.5 & 4.5 & $64.3 \%$ \\
\hline S26 & 1 & 1 & 0.5 & 0.5 & 0.5 & 0.5 & 0.5 & 4.5 & $64.3 \%$ & S97 & 1 & 1 & 0.5 & 1 & 0.5 & 0.5 & 0.5 & 5 & $71.4 \%$ \\
\hline S27 & 1 & 1 & 0.5 & 1 & 0.5 & 0.5 & 0.5 & 5 & $71.4 \%$ & S98 & 1 & 1 & 0.5 & 1 & 0.5 & 0.5 & 0.5 & 5 & $71.4 \%$ \\
\hline S28 & 1 & 1 & 0.5 & 1 & 1 & 0.5 & 0.5 & 5.5 & $78.6 \%$ & S99 & 1 & 1 & 0.5 & 1 & 0.5 & 0.5 & 1 & 5.5 & $78.6 \%$ \\
\hline S29 & 1 & 1 & 0.5 & 1 & 0.5 & 1 & 1 & 6 & $85.7 \%$ & S100 & 1 & 1 & 0.5 & 1 & 0.5 & 0.5 & 1 & 5.5 & $78.6 \%$ \\
\hline $\mathrm{S} 30$ & 1 & 1 & 0.5 & 1 & 0.5 & 0.5 & 1 & 5.5 & $78.6 \%$ & S101 & 1 & 1 & 0.5 & 0.5 & 0.5 & 1 & 1 & 5.5 & $78.6 \%$ \\
\hline S31 & 1 & 1 & 0.5 & 0.5 & 0.5 & 1 & 1 & 5.5 & $78.6 \%$ & S102 & 1 & 1 & 1 & 1 & 1 & 0.5 & 0.5 & 6 & $85.7 \%$ \\
\hline S32 & 1 & 1 & 1 & 1 & 1 & 0.5 & 0.5 & 6 & $85.7 \%$ & S103 & 1 & 1 & 0.5 & 0.5 & 0.5 & 0.5 & 0.5 & 4.5 & $64.3 \%$ \\
\hline
\end{tabular}


Table A1. Cont.

\begin{tabular}{|c|c|c|c|c|c|c|c|c|c|c|c|c|c|c|c|c|c|c|c|}
\hline Study & Q1 & Q2 & Q3 & Q4 & Q5 & Q6 & Q7 & Total & Percentage & Study & Q1 & Q2 & Q3 & Q4 & Q5 & Q6 & Q7 & Total & Percentage \\
\hline S33 & 1 & 1 & 0.5 & 0.5 & 0.5 & 0.5 & 0.5 & 4.5 & $64.3 \%$ & S104 & 1 & 1 & 0.5 & 1 & 0.5 & 1 & 1 & 6 & $85.7 \%$ \\
\hline S34 & 1 & 1 & 0.5 & 0 & 0.5 & 1 & 1 & 5 & $71.4 \%$ & S105 & 1 & 1 & 0.5 & 1 & 1 & 0.5 & 0.5 & 5.5 & $78.6 \%$ \\
\hline S35 & 1 & 1 & 0.5 & 1 & 1 & 0.5 & 0.5 & 5.5 & $78.6 \%$ & S106 & 1 & 1 & 0.5 & 0.5 & 1 & 1 & 0.5 & 5.5 & $78.6 \%$ \\
\hline S37 & 1 & 1 & 0.5 & 1 & 0.5 & 0.5 & 0.5 & 5 & $71.4 \%$ & S108 & 1 & 1 & 1 & 1 & 1 & 0.5 & 0.5 & 6 & $85.7 \%$ \\
\hline S38 & 1 & 1 & 1 & 1 & 1 & 0.5 & 0.5 & 6 & $85.7 \%$ & S109 & 1 & 1 & 1 & 0.5 & 0.5 & 0.5 & 0.5 & 5 & $71.4 \%$ \\
\hline S39 & 1 & 1 & 1 & 0.5 & 0.5 & 0.5 & 0.5 & 5 & $71.4 \%$ & S110 & 1 & 1 & 0.5 & 0.5 & 0.5 & 0.5 & 0.5 & 4.5 & $64.3 \%$ \\
\hline S40 & 1 & 1 & 0.5 & 0.5 & 0.5 & 0.5 & 0.5 & 4.5 & $64.3 \%$ & S111 & 1 & 1 & 0.5 & 1 & 0.5 & 0.5 & 0.5 & 5 & $71.4 \%$ \\
\hline $\mathrm{S} 42$ & 1 & 1 & 0.5 & 1 & 0.5 & 0.5 & 0.5 & 5 & $71.4 \%$ & S113 & 1 & 1 & 0.5 & 1 & 0.5 & 0.5 & 1 & 5.5 & $78.6 \%$ \\
\hline S43 & 1 & 1 & 0.5 & 0.5 & 0.5 & 0.5 & 1 & 5 & $71.4 \%$ & S114 & 1 & 1 & 1 & 1 & 1 & 1 & 1 & 7 & $100.0 \%$ \\
\hline S44 & 1 & 1 & 0.5 & 1 & 0.5 & 1 & 1 & 6 & $85.7 \%$ & S115 & 1 & 1 & 0.5 & 0.5 & 0.5 & 1 & 1 & 5.5 & $78.6 \%$ \\
\hline S45 & 1 & 1 & 0.5 & 0.5 & 0.5 & 1 & 1 & 5.5 & $78.6 \%$ & S116 & 1 & 1 & 1 & 1 & 1 & 0.5 & 0.5 & 6 & $85.7 \%$ \\
\hline S46 & 1 & 1 & 1 & 1 & 1 & 0.5 & 0.5 & 6 & $85.7 \%$ & S117 & 1 & 1 & 0.5 & 0.5 & 0.5 & 0.5 & 0.5 & 4.5 & $64.3 \%$ \\
\hline S47 & 1 & 1 & 0.5 & 0.5 & 0.5 & 0.5 & 0.5 & 4.5 & $64.3 \%$ & S118 & 1 & 1 & 0.5 & 1 & 0.5 & 1 & 1 & 6 & $85.7 \%$ \\
\hline S48 & 1 & 1 & 0.5 & 1 & 0.5 & 1 & 1 & 6 & $85.7 \%$ & S119 & 1 & 1 & 0.5 & 1 & 1 & 0.5 & 0.5 & 5.5 & $78.6 \%$ \\
\hline S49 & 1 & 1 & 0.5 & 1 & 1 & 0.5 & 0.5 & 5.5 & $78.6 \%$ & S120 & 1 & 1 & 0.5 & 0.5 & 1 & 0.5 & 0.5 & 5 & $71.4 \%$ \\
\hline S50 & 1 & 1 & 0.5 & 0.5 & 1 & 0.5 & 0.5 & 5 & $71.4 \%$ & S121 & 1 & 1 & 0.5 & 1 & 0.5 & 0.5 & 0.5 & 5 & $71.4 \%$ \\
\hline S52 & 1 & 1 & 1 & 1 & 1 & 0.5 & 0.5 & 6 & $85.7 \%$ & S123 & 1 & 1 & 1 & 1 & 0.5 & 0.5 & 0.5 & 5.5 & $78.6 \%$ \\
\hline S53 & 1 & 1 & 1 & 0.5 & 0.5 & 1 & 0.5 & 5.5 & $78.6 \%$ & S124 & 1 & 1 & 0.5 & 0.5 & 0.5 & 0.5 & 0.5 & 4.5 & $64.3 \%$ \\
\hline S54 & 1 & 1 & 0.5 & 0.5 & 0.5 & 1 & 0.5 & 5 & $71.4 \%$ & S125 & 1 & 1 & 0.5 & 1 & 1 & 0.5 & 0.5 & 5.5 & $78.6 \%$ \\
\hline S55 & 1 & 1 & 0.5 & 1 & 0.5 & 0.5 & 0.5 & 5 & $71.4 \%$ & S126 & 1 & 1 & 0.5 & 1 & 0.5 & 0.5 & 0.5 & 5 & $71.4 \%$ \\
\hline S56 & 1 & 1 & 0.5 & 1 & 0.5 & 0.5 & 1 & 5.5 & $78.6 \%$ & S127 & 1 & 1 & 0.5 & 1 & 0.5 & 0.5 & 1 & 5.5 & $78.6 \%$ \\
\hline S57 & 1 & 1 & 0.5 & 1 & 0.5 & 0.5 & 0.5 & 5 & $71.4 \%$ & S128 & 1 & 1 & 0.5 & 1 & 0.5 & 0.5 & 1 & 5.5 & $78.6 \%$ \\
\hline S58 & 1 & 1 & 0.5 & 1 & 0.5 & 0.5 & 1 & 5.5 & $78.6 \%$ & S129 & 1 & 1 & 0.5 & 0.5 & 0.5 & 1 & 1 & 5.5 & $78.6 \%$ \\
\hline S59 & 1 & 1 & 0.5 & 0.5 & 0.5 & 1 & 1 & 5.5 & $78.6 \%$ & S130 & 1 & 1 & 1 & 1 & 1 & 0.5 & 1 & 6.5 & $92.9 \%$ \\
\hline S60 & 1 & 1 & 1 & 1 & 1 & 0.5 & 0.5 & 6 & $85.7 \%$ & S131 & 1 & 1 & 0.5 & 0.5 & 0.5 & 0.5 & 0.5 & 4.5 & $64.3 \%$ \\
\hline S61 & 1 & 1 & 0.5 & 0.5 & 0.5 & 0.5 & 0.5 & 4.5 & $64.3 \%$ & S132 & 1 & 1 & 1 & 1 & 1 & 1 & 1 & 7 & $100.0 \%$ \\
\hline S62 & 1 & 1 & 0.5 & 1 & 0.5 & 1 & 1 & 6 & $85.7 \%$ & S133 & 1 & 1 & 0.5 & 1 & 1 & 0.5 & 0.5 & 5.5 & $78.6 \%$ \\
\hline S63 & 1 & 1 & 0.5 & 1 & 1 & 0.5 & 0.5 & 5.5 & $78.6 \%$ & S134 & 1 & 1 & 0.5 & 0.5 & 1 & 0.5 & 0.5 & 5 & $71.4 \%$ \\
\hline S64 & 1 & 1 & 0.5 & 0.5 & 1 & 0.5 & 0.5 & 5 & $71.4 \%$ & S135 & 1 & 1 & 0.5 & 0.5 & 0.5 & 0.5 & 0.5 & 4.5 & $64.3 \%$ \\
\hline S65 & 1 & 1 & 0.5 & 1 & 0.5 & 0.5 & 0.5 & 5 & $71.4 \%$ & S136 & 1 & 1 & 1 & 1 & 1 & 0.5 & 0.5 & 6 & $85.7 \%$ \\
\hline S66 & 1 & 1 & 1 & 1 & 1 & 0.5 & 0.5 & 6 & $85.7 \%$ & S137 & 1 & 1 & 1 & 0.5 & 1 & 0.5 & 0.5 & 5.5 & $78.6 \%$ \\
\hline
\end{tabular}


Table A1. Cont.

\begin{tabular}{|c|c|c|c|c|c|c|c|c|c|c|c|c|c|c|c|c|c|c|c|}
\hline Study & Q1 & Q2 & Q3 & Q4 & Q5 & Q6 & Q7 & Total & Percentage & Study & Q1 & Q2 & Q3 & Q4 & Q5 & Q6 & Q7 & Total & Percentage \\
\hline S67 & 1 & 1 & 1 & 0.5 & 0.5 & 0.5 & 0.5 & 5 & $71.4 \%$ & S138 & 1 & 1 & 0.5 & 0.5 & 1 & 0.5 & 0.5 & 5 & $71.4 \%$ \\
\hline S68 & 1 & 1 & 0.5 & 0.5 & 0.5 & 0.5 & 0.5 & 4.5 & $64.3 \%$ & S139 & 1 & 1 & 0.5 & 1 & 0.5 & 0.5 & 0.5 & 5 & $71.4 \%$ \\
\hline S69 & 1 & 1 & 0.5 & 1 & 0.5 & 0.5 & 0.5 & 5 & $71.4 \%$ & S140 & 1 & 1 & 0.5 & 1 & 1 & 0.5 & 0.5 & 5.5 & $78.6 \%$ \\
\hline S71 & 1 & 1 & 0.5 & 1 & 0.5 & 0.5 & 1 & 5.5 & $78.6 \%$ & $\mathrm{~S} 142$ & 1 & 1 & 0.5 & 0.5 & 1 & 0.5 & 0.5 & 5 & $71.4 \%$ \\
\hline
\end{tabular}

\section{Appendix B}

Table A2. Full list of the included publications.

\begin{tabular}{|c|c|c|c|c|c|c|c|c|}
\hline Sr. & Source & Year & Article Type & Studied Technology & Sample Size & Sample Type & Country & Acceptance Model \\
\hline 1 & $\begin{array}{c}\text { Bennani and Oumlil } \\
\text { [84] }\end{array}$ & 2010 & Conference & ICT Appropriation & 111 & $\begin{array}{l}\text { Physicians and } \\
\text { Nurses }\end{array}$ & Morocco & TAM \\
\hline 2 & Lai and $\mathrm{Li}$ [85] & 2010 & Conference & $\begin{array}{l}\text { Computer Assistance } \\
\text { Orthopedic Surgery System }\end{array}$ & 115 & $\begin{array}{c}\text { Healthcare } \\
\text { Professionals }\end{array}$ & Taiwan & $\begin{array}{c}\text { Integrated Model: TAM } \\
\text { and TPB }\end{array}$ \\
\hline 3 & Kim et al. [86] & 2010 & Journal Article & $\begin{array}{l}\text { Tele-Homecare Technology } \\
\text { (Telemedicine) }\end{array}$ & 40 & Physicians & USA & $\begin{array}{c}\text { Compare Two Models: } \\
\text { TAM and TPB }\end{array}$ \\
\hline 4 & Holtz [87] & 2010 & PHD Dissertation & Electronic Medical Records & 113 & Nurses & USA & UTAUT \\
\hline 5 & Pai and Huang [88] & 2011 & Journal Article & $\begin{array}{l}\text { Healthcare Information } \\
\text { Systems }\end{array}$ & 366 & $\begin{array}{c}\text { Nurses, Head } \\
\text { Directors, and Other } \\
\text { Related Personnel }\end{array}$ & Taiwan & $\begin{array}{l}\text { Integrated Model: TAM } \\
\text { and IS Success Model }\end{array}$ \\
\hline 6 & Orruño et al. [89] & 2011 & Journal Article & Tele-Dermatology System & 171 & Physicians & Spain & Modified TAM \\
\hline 7 & Maarop et al. [90] & 2011 & Conference & Teleconsultation Technology & 72 & Healthcare Providers & Malaysia & Extended TAM \\
\hline 8 & $\begin{array}{l}\text { Schnall and } \\
\text { Bakken [91] }\end{array}$ & 2011 & Journal Article & $\begin{array}{c}\text { Continuity of Care Record } \\
\text { (CCR) with } \\
\text { Context-Specific Links }\end{array}$ & 94 & HIV Case Managers & USA & Extended TAM \\
\hline
\end{tabular}


Table A2. Cont.

\begin{tabular}{|c|c|c|c|c|c|c|c|c|}
\hline Sr. & Source & Year & Article Type & Studied Technology & Sample Size & Sample Type & Country & Acceptance Model \\
\hline 10 & Damanhoori et al. [93] & 2011 & Conference & $\begin{array}{l}\text { Breast Self-Examination } \\
\text { Teleconsultation }\end{array}$ & 279 & Female Citizens & Malaysia & TAM \\
\hline 11 & Lim et al. [94] & 2011 & Journal Article & $\begin{array}{l}\text { Mobile Phones to Seek } \\
\text { Health Information }\end{array}$ & 175 & Female Citizens 21+ & Singapore & Extended TAM \\
\hline 12 & $\begin{array}{l}\text { Mohamed, Tawfik, } \\
\text { and Norton [95] }\end{array}$ & 2011 & Conference & $\begin{array}{l}\text { Electronic Health } \\
\text { Technologies }\end{array}$ & 50 & $\begin{array}{l}\text { Participants-Not } \\
\text { Specified }\end{array}$ & UAE and UK & $\begin{array}{c}\text { E-Health Technology } \\
\text { Acceptance Model (E- } \\
\text { HTAM)_Extended TAM }\end{array}$ \\
\hline 14 & $\begin{array}{l}\text { Mohamed, Tawfik, } \\
\text { and Al-Jumeily [97] }\end{array}$ & 2011 & Conference & $\begin{array}{l}\text { Smart Mobile Phone in the } \\
\text { Medical Domain }\end{array}$ & 229 & $\begin{array}{l}\text { Students Medical } \\
\text { Practitioners, Ministry } \\
\text { of Health Staff and } \\
\text { Universities Staff }\end{array}$ & UAE and UK & $\begin{array}{c}\text { Mobile Technology } \\
\text { Acceptance Model (Mo- } \\
\text { HTAM)_Extended TAM }\end{array}$ \\
\hline 15 & Ketikidis et al. [7] & 2012 & Journal Article & $\begin{array}{l}\text { Health Information } \\
\text { Technology (HIT) }\end{array}$ & 133 & $\begin{array}{c}\text { Healthcare } \\
\text { Professionals: Doctors } \\
\text { and Nurses }\end{array}$ & $\begin{array}{l}\text { North } \\
\text { Macedonia }\end{array}$ & Modified TAM2 \\
\hline 17 & Kim and Park [99] & 2012 & Journal Article & $\begin{array}{l}\text { Health Information } \\
\text { Technology (HIT) }\end{array}$ & 728 & $\begin{array}{l}\text { Users of Online } \\
\text { Health Information }\end{array}$ & South Korea & $\begin{array}{l}\text { Integrated Model-Health } \\
\text { Information Technology } \\
\text { Acceptance Model } \\
\text { (HITAM): HBM, TPB, } \\
\text { and TAM }\end{array}$ \\
\hline
\end{tabular}


Table A2. Cont.

\begin{tabular}{|c|c|c|c|c|c|c|c|c|}
\hline Sr. & Source & Year & Article Type & Studied Technology & Sample Size & Sample Type & Country & Acceptance Model \\
\hline 18 & Terrizzi et al. [100] & 2012 & Conference & $\begin{array}{l}\text { Integrated Electronic Health } \\
\text { Records (IEHR) }\end{array}$ & 31 & $\begin{array}{l}\text { Physicians and Office } \\
\text { Staff }\end{array}$ & USA & Extended TAM \\
\hline 19 & Chow et al. [101] & 2012 & Journal Article & $\begin{array}{l}\text { Online Virtual Health } \\
\text { Learning: Rapid Sequence } \\
\text { Intubation (RSI) }\end{array}$ & 206 & Nursing Students & Hong Kong & Extended TAM \\
\hline 20 & Asua et al. [102] & 2012 & Journal Article & Telemonitoring System & 268 & $\begin{array}{l}\text { Nurses, General } \\
\text { Practitioners, and } \\
\text { Pediatricians }\end{array}$ & Spain & Extended TAM \\
\hline 21 & $\begin{array}{l}\text { Khalika Banda and } \\
\text { Gombachika [103] }\end{array}$ & 2012 & Conference & Mobile Health Services & 38 & $\begin{array}{l}\text { Health Surveillance } \\
\text { Assistants }\end{array}$ & Malawi & Extended TAM \\
\hline 22 & Holden et al. [104] & 2012 & Journal Article & $\begin{array}{c}\text { Bar-coded medication } \\
\text {-dispensing and } \\
\text { administration technology }\end{array}$ & 39 & $\begin{array}{c}\text { Pharmacists and } \\
\text { Pharmacy Technicians }\end{array}$ & USA & Extended TAM \\
\hline 23 & Chang and Hsu [105] & 2012 & Journal Article & $\begin{array}{l}\text { Online Patient-Safety } \\
\text { Reporting System }\end{array}$ & 183 & $\begin{array}{l}\text { Healthcare } \\
\text { Professionals }\end{array}$ & Taiwan & Modified UTAUT \\
\hline 25 & Moores [107] & 2012 & Journal Article & Clinical Management System & 346 & Clinical Staff & France & $\begin{array}{c}\text { Extended } \\
\text { TAM-Integrated Model }\end{array}$ \\
\hline 26 & Guo et al. [108] & 2012 & Conference & Mobile Health Services & 492 & Service Participants & Taiwan & Extended TAM \\
\hline 27 & Sarlan et al. [109] & 2012 & Conference & Clinic Information System & 252 & Doctors and Staff & Malaysia & $\begin{array}{c}\text { Integrated Model: TAM } \\
\text { and TPB }\end{array}$ \\
\hline 28 & Gagnon et al. [110] & 2012 & Journal Article & Home Telemonitoring System & 93 & Doctors and Nurses & Spain & Modified TAM \\
\hline 29 & Chua et al. [111] & 2012 & Conference & Home-based Pill Dispensers & 21 & Patients & Singapore & TAM \\
\hline 30 & $\begin{array}{l}\text { Su, Tsai, and } \\
\text { Chen [112] }\end{array}$ & 2012 & Conference & Telecare System & 365 & Older Resident & Taiwan & TAM \\
\hline 31 & Chow et al. [113] & 2013 & Journal Article & Clinical Imaging Portal & 128 & Nursing Students & Hong Kong & Extended TAM \\
\hline
\end{tabular}


Table A2. Cont.

\begin{tabular}{|c|c|c|c|c|c|c|c|c|}
\hline Sr. & Source & Year & Article Type & Studied Technology & Sample Size & Sample Type & Country & Acceptance Model \\
\hline 32 & Cheng [114] & 2013 & Journal Article & E-Learning System & 218 & Nurses & Taiwan & $\begin{array}{l}\text { Integrated Model: TAM } \\
\text { and Flow Theory }\end{array}$ \\
\hline 33 & $\begin{array}{l}\text { Bennani and } \\
\text { Oumlil [28] }\end{array}$ & 2013 & Conference & IT in Healthcare & 250 & Nurses & Morocco & Extended UTAUT \\
\hline 34 & $\begin{array}{l}\text { Vanneste, Vermeulen, } \\
\text { and Declercq [115] }\end{array}$ & 2013 & Journal Article & $\begin{array}{c}\text { BelRAI Web Application: } \\
\text { Web-Based System Enabling } \\
\text { Person-Centered Recording } \\
\text { and Data Sharing }\end{array}$ & 282 & $\begin{array}{l}\text { Healthcare } \\
\text { Professionals }\end{array}$ & Belgium & Extended UTAUT \\
\hline 35 & Huang [116] & 2013 & Journal Article & Telecare & 369 & Residents 15+ & Taiwan & Extended TAM \\
\hline 37 & $\begin{array}{l}\text { Arning, Kowalewski, } \\
\text { and Ziefle [118] }\end{array}$ & 2013 & Conference & $\begin{array}{c}\text { Wireless Medical } \\
\text { Technologies (WMT) }\end{array}$ & 305 & Users/Non-Users & Germany & $\begin{array}{c}\text { Innovation Diffusion } \\
\text { Theory }\end{array}$ \\
\hline 38 & $\begin{array}{l}\text { Sarlan, Ahmad, and } \\
\text { Fatimah [119] }\end{array}$ & 2013 & Conference & $\begin{array}{l}\text { Health Information } \\
\text { System (HIS) }\end{array}$ & 252 & $\begin{array}{l}\text { Staff in Private } \\
\text { Healthcare } \\
\text { Organizations }\end{array}$ & Malaysia & $\begin{array}{c}\text { Integrated Model: TAM } \\
\text { and TPB }\end{array}$ \\
\hline 39 & Cocosila [120] & 2013 & Journal Article & Mobile Health Applications & 170 & Smokers (18+) & United Kingdom & $\begin{array}{c}\text { Attitude-Perceived } \\
\text { Risk-Motivation Model }\end{array}$ \\
\hline 40 & $\begin{array}{l}\text { Gajanayake, Sahama, } \\
\text { and Iannella [58] }\end{array}$ & 2013 & Journal Article & $\begin{array}{l}\text { Electronic Health } \\
\text { Record (EHR) }\end{array}$ & 334 & $\begin{array}{l}\text { Medical, Nursing, and } \\
\text { Health Students }\end{array}$ & Australia & TAM \\
\hline 41 & Chen et al. [121] & 2013 & Journal Article & E-Appointment System & 334 & Citizens & Taiwan & Extended TAM \\
\hline 42 & $\begin{array}{l}\text { Kummer, Schäfer, and } \\
\text { Todorova [122] }\end{array}$ & 2013 & Journal Article & $\begin{array}{c}\text { Sensor-Based Medication } \\
\text { Systems }\end{array}$ & 579 & Nurses & Australia & Extended TAM2 \\
\hline 43 & $\begin{array}{l}\text { Kuo, Liu, and } \\
\text { Ma [123] }\end{array}$ & 2013 & Journal Article & $\begin{array}{l}\text { Mobile Electronic Medical } \\
\text { Record (MEMR) }\end{array}$ & 665 & Nurses & Taiwan & Extended TAM \\
\hline 44 & $\begin{array}{c}\text { Krueklai, Kiattisin, } \\
\text { and Leelasantitham } \\
{[124]}\end{array}$ & 2013 & Journal Article & E-Health Solutions & 200 & $\begin{array}{l}\text { Participants from } \\
\text { Government } \\
\text { Hospitals }\end{array}$ & Thailand & UTAUT \\
\hline
\end{tabular}


Table A2. Cont.

\begin{tabular}{|c|c|c|c|c|c|c|c|c|}
\hline Sr. & Source & Year & Article Type & Studied Technology & Sample Size & Sample Type & Country & Acceptance Model \\
\hline 45 & $\begin{array}{l}\text { Manimaran and } \\
\text { Lakshmi [125] }\end{array}$ & 2013 & Journal Article & $\begin{array}{c}\text { Health Management } \\
\text { Information System (HMIS) }\end{array}$ & 960 & $\begin{array}{c}\text { Healthcare } \\
\text { Professionals: Doctors, } \\
\text { Pharmacists, } \\
\text { Nurses, etc. }\end{array}$ & India & Extended TAM \\
\hline 46 & Tavakoli et al. [126] & 2013 & Journal Article & $\begin{array}{l}\text { Electronic Medical } \\
\text { Record (EMR) }\end{array}$ & 62 & System Users & Iran & Extended TAM \\
\hline 47 & $\begin{array}{l}\text { Jackson, Yi, and } \\
\text { Park [127] }\end{array}$ & 2013 & Journal Article & $\begin{array}{l}\text { Personal Digital } \\
\text { Assistant (PDA) }\end{array}$ & 222 & Physicians & USA & TAM, TPB, and IDT \\
\hline 48 & Mohamed et al. [128] & 2013 & Conference & $\begin{array}{l}\text { Electronic Health } \\
\text { Technologies }\end{array}$ & 129 & $\begin{array}{l}\text { Participants-Not } \\
\text { Specified }\end{array}$ & UAE and UK & $\begin{array}{c}\text { E-Health Technology } \\
\text { Acceptance Model (E- } \\
\text { HTAM2)_Extended TAM }\end{array}$ \\
\hline 49 & $\begin{array}{l}\text { Sarlan, Ahmad, and } \\
\text { Ahmad [62] }\end{array}$ & 2013 & Journal Article & $\begin{array}{l}\text { Clinic Information } \\
\text { System (CIS) }\end{array}$ & 252 & Doctors and Staff & Malaysia & $\begin{array}{c}\text { Extended Hybrid Model: } \\
\text { TAM and TPB }\end{array}$ \\
\hline 50 & Ford [129] & 2014 & Master's Thesis & $\begin{array}{l}\text { Over-the-Counter Blood } \\
\text { Pressure Monitor }\end{array}$ & 26 & $\begin{array}{l}\text { Individuals in } 2 \text { age } \\
\text { groups: }(18-28) \text { and } \\
(60-85)\end{array}$ & USA & Extended UTAUT \\
\hline 52 & Lin [131] & 2014 & Journal Article & $\begin{array}{c}\text { Knowledge Management } \\
\text { Systems }\end{array}$ & 361 & Physicians & USA and Taiwan & $\begin{array}{l}\text { Technology Acceptance } \\
\text { View of Knowledge } \\
\text { Management Systems in } \\
\text { Healthcare Organizations } \\
\text { (TAV-KMSHO) }\end{array}$ \\
\hline 53 & $\begin{array}{l}\text { Hsieh, Lai, and } \\
\text { Ye [132] }\end{array}$ & 2014 & Conference & Health Cloud Services & 443 & Patients & Taiwan & $\begin{array}{l}\text { Integrated Model: TAM } \\
\text { and SQB }\end{array}$ \\
\hline 54 & Gagnon et al. [133] & 2014 & Journal Article & $\begin{array}{l}\text { Electronic Health Record } \\
\text { (EHR) }\end{array}$ & 150 & Physicians & Canada & $\begin{array}{l}4 \text { Models: TAM, Extended } \\
\text { TAM, Psychosocial Model, } \\
\text { and Integrated Model }\end{array}$ \\
\hline
\end{tabular}


Table A2. Cont.

\begin{tabular}{|c|c|c|c|c|c|c|c|c|}
\hline Sr. & Source & Year & Article Type & Studied Technology & Sample Size & Sample Type & Country & Acceptance Model \\
\hline 55 & Fleming et al. [134] & 2014 & Journal Article & $\begin{array}{l}\text { Prescription Monitoring: } \\
\text { Prescription Access }\end{array}$ & 76 & Emergency Physicians & USA & TAM \\
\hline 56 & Corneille et al. [135] & 2014 & Conference & $\begin{array}{l}\text { Text-Message-Based Health } \\
\text { Intervention }\end{array}$ & 120 & $\begin{array}{c}\text { Undergraduate } \\
\text { Psychology Students }\end{array}$ & USA & $\begin{array}{c}\text { Innovation Diffusion } \\
\text { Theory }\end{array}$ \\
\hline 57 & Steininger et al. [136] & 2014 & Conference & $\begin{array}{l}\text { Electronic Health } \\
\text { Record (EHR) }\end{array}$ & 204 & Physicians & Austria & Modified TAM \\
\hline 58 & $\begin{array}{c}\text { Hwang, Kim, and } \\
\text { Lee [137] }\end{array}$ & 2014 & Journal Article & $\begin{array}{c}\text { Ambulance Telemetry } \\
\text { Technology }\end{array}$ & 136 & $\begin{array}{l}\text { Emergency Medical } \\
\text { Technicians }\end{array}$ & S. Korea & Extended TAM \\
\hline 59 & $\begin{array}{l}\text { Hung, Tsai, and } \\
\text { Chuang [138] }\end{array}$ & 2014 & Journal Article & $\begin{array}{l}\text { Primary Health Information } \\
\text { System (PHIS) }\end{array}$ & 768 & Nurses & Taiwan & $\begin{array}{c}\text { Theory of Reasoned } \\
\text { Action (TRA) }\end{array}$ \\
\hline 60 & $\begin{array}{l}\text { Rho, Choi, and } \\
\text { Lee [139] }\end{array}$ & 2014 & Journal Article & Telemedicine Technology & 183 & Physicians & S. Korea & Extended TAM \\
\hline 61 & $\begin{array}{l}\text { Moon and } \\
\text { Chang [140] }\end{array}$ & 2014 & Journal Article & Innovative Smartphone & 122 & Hospital Professionals & S. Korea & $\begin{array}{c}\text { Integrated Model: TRA, } \\
\text { TAM, and IS } \\
\text { Success Model }\end{array}$ \\
\hline 63 & Yallah [142] & 2014 & PhD Dissertation & Telemedicine & 190 & Physicians & Georgia & Extended TAM \\
\hline 64 & Cleveland [143] & 2014 & PhD Dissertation & Educational Technology & 57 & Nurse Educators & USA & Extended TAM \\
\hline 65 & Devine [144] & 2015 & PhD Dissertation & Social Media in Healthcare & 137 & Nurses & USA & UTAUT2 \\
\hline 66 & Ebie and Njoku [145] & 2015 & Journal Article & $\begin{array}{l}\text { Performance Appraisal } \\
\text { System }\end{array}$ & 80 & Line Managers & United Kingdom & Extended TAM \\
\hline 67 & $\begin{array}{l}\text { Krishnan, Dhillon, } \\
\text { and Lutteroth [146] }\end{array}$ & 2015 & Conference & $\begin{array}{c}\text { Consumer Health Informatics } \\
\text { Applications }\end{array}$ & 105 & Health Consumers & Malaysia & $\begin{array}{c}\text { Integrated Model: TAM, } \\
\text { TRA, and UTAUT2 }\end{array}$ \\
\hline 68 & $\begin{array}{l}\text { Basak, Gumussoy, and } \\
\text { Calisir [147] }\end{array}$ & 2015 & Journal Article & $\begin{array}{l}\text { Personal Digital Assistant } \\
\text { (PDA) }\end{array}$ & 339 & Physicians & Turkey & Extended TAM \\
\hline
\end{tabular}


Table A2. Cont.

\begin{tabular}{|c|c|c|c|c|c|c|c|c|}
\hline Sr. & Source & Year & Article Type & Studied Technology & Sample Size & Sample Type & Country & Acceptance Model \\
\hline 69 & $\begin{array}{c}\text { Briz-Ponce and } \\
\text { García-Peñalvo [148] }\end{array}$ & 2015 & Journal Article & $\begin{array}{l}\text { Mobile Technology and } \\
\text { "Apps" in Medical Education }\end{array}$ & 124 & $\begin{array}{l}\text { Students and Medical } \\
\text { Professionals }\end{array}$ & Spain & Extended TAM \\
\hline 70 & $\begin{array}{l}\text { Song, Park, and } \\
\text { Oh [149] }\end{array}$ & 2015 & Journal Article & $\begin{array}{c}\text { Bar Code Medication } \\
\text { Administration Technology }\end{array}$ & 163 & Nurses & USA & Extended TAM \\
\hline 71 & Holahan et al. [150] & 2015 & Journal Article & $\begin{array}{c}\text { Medication Reconciliation } \\
\text { Technology }\end{array}$ & 53 & $\begin{array}{l}\text { Primary Care } \\
\text { Providers }\end{array}$ & USA & $\begin{array}{c}\text { Effective Technology Use } \\
\text { Model (ETUM) }\end{array}$ \\
\hline 72 & Ahadzadeh et al. [151] & 2015 & Journal Article & Health-Related Internet Use & 293 & Female Users & Malaysia & $\begin{array}{c}\text { Integrated Model: HBM } \\
\text { and TAM }\end{array}$ \\
\hline 73 & $\begin{array}{l}\text { Kowitlawakul } \\
\text { et al. [152] }\end{array}$ & 2015 & Journal Article & $\begin{array}{l}\text { Electronic Health Records for } \\
\text { Nursing Education (EHRNE) }\end{array}$ & 212 & $\begin{array}{l}\text { Undergraduate } \\
\text { Nurses }\end{array}$ & Singapore & Extended TAM \\
\hline 74 & $\begin{array}{l}\text { Elaklouk, Mat Zin, } \\
\text { and Shapii [153] }\end{array}$ & 2015 & Journal Article & $\begin{array}{c}\text { Serious Games for Cognitive } \\
\text { Rehabilitation }\end{array}$ & 41 & Therapists & Saudi Arabia & Extended TAM \\
\hline 75 & Chang et al. [154] & 2015 & Journal Article & $\begin{array}{c}\text { E-Hospital Service: } \\
\text { Web-Based } \\
\text { Appointment System }\end{array}$ & 140 & Patients & Taiwan & Extended TAM \\
\hline 77 & $\begin{array}{l}\text { Steininger and } \\
\text { Stiglbauer [156] }\end{array}$ & 2015 & Journal Article & $\begin{array}{l}\text { Electronic Health Records } \\
\text { (EHR) }\end{array}$ & 204 & Physicians & Austria & Modified TAM \\
\hline 78 & De Veer et al. [157] & 2015 & Journal Article & E-Health Applications & 1014 & Older People & Germany & UTAUT \\
\hline 79 & $\mathrm{Ku}$ and Hsieh [158] & 2015 & Conference & Health Cloud Services & 105 & Patients & Taiwan & $\begin{array}{l}\text { Integrated Model: TPB } \\
\text { and SQB }\end{array}$ \\
\hline 80 & Liu and Cheng [159] & 2015 & Journal Article & $\begin{array}{l}\text { Mobile Electronic Medical } \\
\text { Records }\end{array}$ & 158 & Physicians & Taiwan & $\begin{array}{l}\text { Integrated Model: TAM } \\
\text { and Dual-Factor Model }\end{array}$ \\
\hline 81 & Miiro and Maiga [160] & 2015 & Book Chapter & Social Networks For E-Health & 278 & Graduate Students & Uganda & $\begin{array}{c}\text { E-Health Social } \\
\text { Networked Model }\end{array}$ \\
\hline
\end{tabular}


Table A2. Cont.

\begin{tabular}{|c|c|c|c|c|c|c|c|c|}
\hline Sr. & Source & Year & Article Type & Studied Technology & Sample Size & Sample Type & Country & Acceptance Model \\
\hline 82 & Zaman [161] & 2015 & Master's Thesis & $\begin{array}{l}\text { Electronic Documentation } \\
\text { Systems (her, EMR, EPR) }\end{array}$ & 248 & Nurses & USA & Extended TAM \\
\hline 83 & $\begin{array}{c}\text { Sezgin and } \\
\text { Özkan-Yıldırım [162] }\end{array}$ & 2016 & Journal Article & $\begin{array}{c}\text { Health Information } \\
\text { Technology: Pharmaceutical } \\
\text { Service Systems }\end{array}$ & 1420 & $\begin{array}{l}\text { Pharmacists/ } \\
\text { Pharmaceutical } \\
\text { Assistants }\end{array}$ & Turkey & $\begin{array}{c}\text { Integrated Model } \\
\text { (P-TAM): TAM, UTAUT, } \\
\text { and TPB }\end{array}$ \\
\hline 84 & Mansur, Fatma [163] & 2016 & Journal Article & $\begin{array}{c}\text { Information and } \\
\text { Communication Technologies }\end{array}$ & 303 & Health Managers & Turkey & Extended TAM \\
\hline 86 & $\mathrm{Ku}$ and Hsieh [165] & 2016 & Conference & $\begin{array}{c}\text { Cloud-Based Healthcare } \\
\text { Services }\end{array}$ & 178 & Elderly Citizens & Taiwan & Extended TPB \\
\hline 87 & $\begin{array}{l}\text { Made Dhanar et al. } \\
\text { [166] }\end{array}$ & 2016 & Conference & Hospital Information Systems & 100 & $\begin{array}{l}\text { Hospital Staff and } \\
\text { Doctors }\end{array}$ & Indonesia & $\begin{array}{c}\text { Integrated Model: TAM } \\
\text { and DeLone and McLean } \\
\text { IS Success }\end{array}$ \\
\hline 88 & Kim, Seok, et al. [31] & 2016 & Journal Article & $\begin{array}{c}\text { Mobile Electronic Medical } \\
\text { Record (EMR) }\end{array}$ & 449 & $\begin{array}{l}\text { Healthcare } \\
\text { Professionals }\end{array}$ & S. Korea & Extended UTAUT \\
\hline 89 & $\begin{array}{c}\text { Cimperman, Makovec } \\
\text { Brenčič, and } \\
\text { Trkman [35] }\end{array}$ & 2016 & Journal Article & $\begin{array}{l}\text { Home Telehealth Services } \\
\text { (HTS) }\end{array}$ & 400 & Old Users $50+$ & Slovenia & Extended UTAUT \\
\hline 90 & Hadadgar et al. [39] & 2016 & Journal Article & $\begin{array}{l}\text { E-Learning Continuing } \\
\text { Medical Education (CME) }\end{array}$ & 146 & General Practitioners & Iran & $\mathrm{TPB}$ \\
\hline 91 & Hsiao and Chen [167] & 2016 & Journal Article & $\begin{array}{l}\text { Computerized Clinical } \\
\text { Practice Guidelines }\end{array}$ & 238 & Physicians & Taiwan & $\begin{array}{c}\text { Integrative Model of } \\
\text { Activity Theory and TAM }\end{array}$ \\
\hline 92 & Lazard et al. [168] & 2016 & Journal Article & Patient Portal & 333 & Portal Users & USA & Extended TAM \\
\hline 93 & Lin et al. [169] & 2016 & Journal Article & Wearable Instrumented Vest & 50 & Elderly $60+$ & Taiwan & Extended TAM \\
\hline 94 & $\begin{array}{l}\text { Al-Nassar, Rababah, } \\
\text { and Al-Nsour [170] }\end{array}$ & 2016 & Journal Article & $\begin{array}{l}\text { Computerized Physician } \\
\text { Order Entry (CPOE) }\end{array}$ & 118 & Physicians & Jordan & Extended TAM \\
\hline
\end{tabular}


Table A2. Cont.

\begin{tabular}{|c|c|c|c|c|c|c|c|c|}
\hline Sr. & Source & Year & Article Type & Studied Technology & Sample Size & Sample Type & Country & Acceptance Model \\
\hline 95 & $\begin{array}{l}\text { Lazuras and } \\
\text { Dokou [171] }\end{array}$ & 2016 & Journal Article & Online Counseling Services & 63 & $\begin{array}{l}\text { Mental Health } \\
\text { Professionals }\end{array}$ & United Kingdom & Extended TAM \\
\hline 96 & $\begin{array}{l}\text { Ifinedo Princely, } \\
\text { Odette Griscti, and } \\
\text { Judy Bailey [172] }\end{array}$ & 2016 & Journal Article & $\begin{array}{l}\text { Healthcare Information } \\
\text { Systems (HIS) }\end{array}$ & 197 & Registered Nurses & Canada & Extended TAM \\
\hline 97 & Holden et al. [173] & 2016 & Journal Article & $\begin{array}{c}\text { In-Room Pediatric ICU } \\
\text { Technology }\end{array}$ & 167 & Nurses & USA & Expanded TAM \\
\hline 99 & $\begin{array}{c}\text { Chen, Chang, and } \\
\text { Lai [175] }\end{array}$ & 2016 & Conference & Cloud Sphygmomanometer & 521 & System Users & Taiwan & Extended TAM \\
\hline 100 & $\begin{array}{l}\text { Guo, Zhang, and } \\
\text { Sun [176] }\end{array}$ & 2016 & Journal Article & Mobile Health Services & 650 & Service Users & China & $\begin{array}{l}\text { Attribute-Perception- } \\
\text { Intention } \\
\text { Model }\end{array}$ \\
\hline 101 & Becker [177] & 2016 & Journal Article & $\begin{array}{c}\text { Mobile Mental Health } \\
\text { Applications }\end{array}$ & 125 & Young Adults & Germany & Extended TAM \\
\hline 102 & $\begin{array}{l}\text { Shujen Lee and } \\
\text { Chen [178] }\end{array}$ & 2016 & Conference & 3D Bio-Printing & 249 & Adults & Taiwan & TAM \\
\hline 103 & Hsieh [179] & 2016 & Journal Article & Health Cloud Services & 681 & Patients & Taiwan & $\begin{array}{l}\text { Dual-Factor Model: } \\
\text { UTAUT and SQB }\end{array}$ \\
\hline 104 & Ahmadi et al. [9] & 2017 & Journal Article & $\begin{array}{c}\text { Picture Archiving and } \\
\text { Communication System } \\
\text { (PACS) }\end{array}$ & 151 & Healthcare Employees & Iran & UTAUT \\
\hline 105 & $\begin{array}{l}\text { Jayusman and } \\
\text { Setyohadi [180] }\end{array}$ & 2017 & Conference & E-Learning System & 188 & $\begin{array}{l}\text { Students at School of } \\
\text { Health Sciences }\end{array}$ & Indonesia & Extended TAM \\
\hline 106 & Amin et al. [181] & 2017 & Journal Article & $\begin{array}{c}\text { Cloud-Based Healthcare } \\
\text { Services }\end{array}$ & 147 & $\begin{array}{c}\text { Healthcare } \\
\text { Professionals }\end{array}$ & $\begin{array}{c}\text { Malaysia, } \\
\text { Pakistan, and } \\
\text { Saudi Arabia }\end{array}$ & UTAUT \\
\hline
\end{tabular}


Table A2. Cont.

\begin{tabular}{|c|c|c|c|c|c|c|c|c|}
\hline Sr. & Source & Year & Article Type & Studied Technology & Sample Size & Sample Type & Country & Acceptance Model \\
\hline 107 & [182] & 2017 & Journal Article & Barcode Technology & 9 & Users & Iran & Extended TAM \\
\hline 108 & Ehteshami [183] & 2017 & Journal Article & $\begin{array}{l}\text { Electronic Health Record } \\
\text { (EHR) }\end{array}$ & 233 & Physicians & Armenia & $\begin{array}{c}\text { Tripolar Model } \\
\text { (TMTA)-Extended TAM }\end{array}$ \\
\hline 109 & $\begin{array}{l}\text { Rajanen and } \\
\text { Weng [184] }\end{array}$ & 2017 & Conference & $\begin{array}{c}\text { Wearable Devices for } \\
\text { Personal Healthcare-Smart } \\
\text { Bands }\end{array}$ & 158 & Consumers & China & Extended TAM \\
\hline 110 & $\begin{array}{c}\text { Wahyuni and } \\
\text { Nurbojatmiko [185] }\end{array}$ & 2017 & Conference & $\begin{array}{l}\text { E-Health Services Consumer } \\
\text { Informatics }\end{array}$ & 91 & Citizens & Indonesia & $\begin{array}{c}\text { Extended Model: TAM } \\
\text { and HBM }\end{array}$ \\
\hline 111 & $\begin{array}{c}\text { Nematollahi et al. } \\
\text { [186] }\end{array}$ & 2017 & Journal Article & $\begin{array}{l}\text { Electronic Medical Records } \\
\text { (EMR) }\end{array}$ & 235 & Hospital Managers & Iran & UTAUT \\
\hline 112 & Hsu and $\mathrm{Wu}[59]$ & 2017 & Journal Article & Nursing Information Systems & 158 & Nurses & Taiwan & TAM \\
\hline 113 & Horne [187] & 2017 & PhD Dissertation & Telemedicine & 46 & Healthcare Workers & USA & TAM \\
\hline 114 & Hsieh et al. [188] & 2017 & Book Chapter & $\begin{array}{l}\text { Personal Health Information } \\
\text { System in Self-Health } \\
\text { Management }\end{array}$ & 240 & $\begin{array}{l}\text { Middle-Aged and } \\
\text { Elderly Citizens }\end{array}$ & Taiwan & HBM \\
\hline 116 & Dou et al. [190] & 2017 & Journal Article & $\begin{array}{l}\text { Smartphone Health } \\
\text { Technology for Chronic } \\
\text { Disease Management }\end{array}$ & 157 & Patients & China & Extended TAM \\
\hline 117 & Zhang et al. [191] & 2017 & Journal Article & Mobile Health Services & 650 & Service Users & China & Extended TAM \\
\hline 118 & Khan et al. [78] & 2018 & Journal Article & E-Prescribing & 295 & Physicians & Pakistan & Extended UTAUT \\
\hline 119 & $\begin{array}{l}\text { Kalavani, Kazerani, } \\
\text { and Shekofteh [65] }\end{array}$ & 2018 & Journal Article & $\begin{array}{l}\text { Evidence-Based Medicine } \\
\text { (EBM) Databases }\end{array}$ & 192 & Medical Residents & Iran & UTAUT \\
\hline 120 & Lin et al. [60] & 2018 & Journal Article & $\begin{array}{c}\text { Wearable Cardiac Health } \\
\text { Technologies }\end{array}$ & 48 & Patients & Taiwan & Extended TAM \\
\hline 121 & Martins et al. [192] & 2018 & Journal Article & E-Health Technology & 210 & Hospital Employees & Nigeria & Extended UTAUT \\
\hline
\end{tabular}


Table A2. Cont.

\begin{tabular}{|c|c|c|c|c|c|c|c|c|}
\hline Sr. & Source & Year & Article Type & Studied Technology & Sample Size & Sample Type & Country & Acceptance Model \\
\hline 122 & $\begin{array}{l}\text { Beldad and } \\
\text { Hegner [67] }\end{array}$ & 2018 & Journal Article & Fitness Apps & 476 & Users of Fitness Apps & Germany & Extended TAM \\
\hline 123 & $\begin{array}{l}\text { Perlich, Meinel, and } \\
\text { Zeis [29] }\end{array}$ & 2018 & Journal Article & $\begin{array}{l}\text { Interactive Documentation } \\
\text { System }\end{array}$ & 46 & $\begin{array}{l}\text { Therapists and } \\
\text { Patients }\end{array}$ & Germany & Extended UTAUT \\
\hline 124 & Nadri et al. [69] & 2018 & Journal Article & Hospital Information Systems & 202 & Systems Users & Iran & Extended TAM \\
\hline 125 & Tubaishat [38] & 2018 & Journal Article & $\begin{array}{l}\text { Electronic Health Records } \\
\text { (EHR) }\end{array}$ & 1539 & Nurse & Jordan & TAM \\
\hline 126 & $\begin{array}{l}\text { Özdemir-Güngör and } \\
\text { Camgöz-Akdağ [61] }\end{array}$ & 2018 & Journal Article & $\begin{array}{l}\text { Electronic Health Records } \\
\text { (EHR) }\end{array}$ & 99 & $\begin{array}{c}\text { Healthcare } \\
\text { Professionals and } \\
\text { Administrative Staff }\end{array}$ & Turkey & Modified TAM \\
\hline 127 & Aldosari et al. [193] & 2018 & Journal Article & $\begin{array}{l}\text { Electronic Medical Records } \\
\text { (EMR) }\end{array}$ & 153 & Nurses & Saudi Arabia & Modified TAM \\
\hline 128 & Ku and Hsieh [194] & 2018 & Conference & $\begin{array}{l}\text { Health Management Mobile } \\
\text { Services }\end{array}$ & 105 & Citizens & Taiwan & $\begin{array}{l}\text { Integrated Model: TPB } \\
\text { and HBM }\end{array}$ \\
\hline 129 & $\begin{array}{l}\text { Hennemann et al. } \\
\text { [195] }\end{array}$ & 2018 & Journal Article & $\begin{array}{l}\text { Occupational } \\
\text { E-Mental-Health }\end{array}$ & 1829 & $\begin{array}{l}\text { Employees with Long } \\
\text { Sick Leaves }\end{array}$ & Germany & Extended UTAUT \\
\hline 130 & $\begin{array}{c}\text { Vitari and } \\
\text { Ologeanu-Taddei } \\
\text { [196] }\end{array}$ & 2018 & Journal Article & $\begin{array}{l}\text { Electronic Health Records } \\
\text { (EHR) }\end{array}$ & $1741+1119$ & $\begin{array}{c}\text { Physicians, } \\
\text { Paraprofessionals, and } \\
\text { Administrative } \\
\text { Personnel }\end{array}$ & France & New Developed Model \\
\hline 131 & Venugopal et al. [10] & 2018 & Conference & $\begin{array}{l}\text { Telemedicine and Electronic } \\
\text { Health Records (EHR) }\end{array}$ & 568 & Clinical Staff & India & UTAUT \\
\hline 132 & Liu and Lee [68] & 2018 & Journal Article & Pharma-Cloud & 179 & Pharmacists & Taiwan & Extended TAM \\
\hline 133 & Zhou et al. [197] & 2019 & Journal Article & Telehealth & 436 & $60+$ Years Old Patients & China & Extended TAM \\
\hline 134 & Francis [198] & 2019 & Journal Article & Self-Monitoring Devices & 258 & Healthcare Providers & USA & Expanded UTAUT2 \\
\hline 135 & Li et al. [63] & 2019 & Journal Article & Smart Wearables & 146 & $60+$ Years Old Adults & China & $\begin{array}{l}\text { Extended Hybrid Model: } \\
\text { TAM and UTAUT }\end{array}$ \\
\hline
\end{tabular}


Table A2. Cont.

\begin{tabular}{|c|c|c|c|c|c|c|c|c|}
\hline Sr. & Source & Year & Article Type & Studied Technology & Sample Size & Sample Type & Country & Acceptance Model \\
\hline 136 & Tao et al. [199] & 2019 & Journal Article & Health Information Portal & 201 & Adults & China & Extended TAM Model \\
\hline 137 & $\begin{array}{l}\text { Masyarakat et al. } \\
{[200]}\end{array}$ & 2019 & Journal Article & Nutrition Information System & 50 & Nutrition Officers & Indonesia & UTAUT \\
\hline 138 & Tsai et al. [64] & 2019 & Journal Article & Telehealth & 281 & Adults $40+$ & Taiwan & $\begin{array}{l}\text { Integrated Model: TAM } \\
\text { and SQB }\end{array}$ \\
\hline 139 & Turja et al. [80] & 2019 & Journal Article & Care Robots & 544 & $\begin{array}{l}\text { Healthcare } \\
\text { Professionals }\end{array}$ & Finland & $\begin{array}{l}\text { Robot Acceptance Model } \\
\text { for Care (RAM-care) }\end{array}$ \\
\hline 140 & Idoga et al. [66] & 2019 & Journal Article & $\begin{array}{l}\text { Cloud-Based Health Center } \\
\text { (CBHC) }\end{array}$ & 300 & $\begin{array}{l}\text { Healthcare } \\
\text { Professionals }\end{array}$ & Nigeria & UTAUT2 \\
\hline 141 & Boon-itt [8] & 2019 & Journal Article & Health Websites & 222 & Internet Consumers & Thailand & Extended TAM \\
\hline 142 & $\begin{array}{l}\text { Schomakers, Lidynia, } \\
\text { and Ziefle [201] }\end{array}$ & 2019 & Conference & $\begin{array}{c}\text { E-Health Technologies: } \\
\text { Fitness Trackers and Remote } \\
\text { Monitoring of Implanted } \\
\text { Cardiac Devices }\end{array}$ & 253 & $\begin{array}{l}\text { Patients with Chronic } \\
\text { Health Conditions }\end{array}$ & Germany & $\begin{array}{l}\text { Acceptance Model of } \\
\text { E-Health Technologies }\end{array}$ \\
\hline
\end{tabular}




\section{References}

1. Taherdoost, H. A review of technology acceptance and adoption models and theories. Procedia Manuf. 2018, 22, 960-967. [CrossRef]

2. Taherdoost, H. Importance of Technology Acceptance Assessment for Successful Implementation and Development of New Technologies. Glob. J. Eng. Sci. 2019, 1. [CrossRef]

3. Chau, P.Y.K.; Hu, P.J.-H. Investigating healthcare professionals' decisions to accept telemedicine technology: An empirical test of competing theories. Inf. Manag. 2002, 39, 297-311. [CrossRef]

4. Al-Qaysi, N.; Mohamad-Nordin, N.; Al-Emran, M. Developing a comprehensive theoretical model for adopting social media in higher education. Interact. Learn. Environ. 2021, 1-22. [CrossRef]

5. Al-Emran, M.; Arpaci, I. Intelligent Systems and Novel Coronavirus (COVID-19): A Bibliometric Analysis. In Emerging Technologies During the Era of COVID-19 Pandemic; Springer: Berlin/Heidelberg, Germany, 2021; pp. 59-67.

6. Rahimi, B.; Nadri, H.; Lotfnezhad Afshar, H.; Timpka, T. A Systematic Review of the Technology Acceptance Model in Health Informatics. Appl. Clin. Inform. 2018, 9, 604-634. [CrossRef]

7. Ketikidis, P.; Dimitrovski, T.; Lazuras, L.; Bath, P.A. Acceptance of health information technology in health professionals: An application of the revised technology acceptance model. Health Inform. J. 2012, 18, 124-134. [CrossRef]

8. Boon-itt, S. Quality of health websites and their influence on perceived usefulness, trust and intention to use: An analysis from Thailand. J. Innov. Entrep. 2019, 8, 4. [CrossRef]

9. Ahmadi, M.; Mehrabi, N.; Sheikhtaheri, A.; Sadeghi, M. Acceptability of picture archiving and communication system (PACS) among hospital healthcare personnel based on a unified theory of acceptance and use of technology. Electron. Physician 2017, 9, 5325-5330. [CrossRef]

10. Venugopal, P.; Priya, S.A.; Manupati, V.K.; Varela, M.L.R.; Machado, J.; Putnik, G.D. Impact of UTAUT Predictors on the Intention and Usage of Electronic Health Records and Telemedicine from the Perspective of Clinical Staffs. In Proceedings of the International Conference on Innovation, Engineering and Entrepreneurship, Guimarães, Portugal, 27-29 June 2018; Springer: Berlin/Heidelberg, Germany, 2018; Volume 505, pp. 172-177.

11. Al-Maroof, R.; Al-Qaysi, N.; Salloum, S.A.; Al-Emran, M. Blended Learning Acceptance: A Systematic Review of Information Systems Models. Technol. Knowl. Learn. 2021, 1-36. [CrossRef]

12. Fishbein, M.; Ajzen, I. Belief, Attitude, Intention, and Behavior: An Introduction to Theory and Research; Addison-Wesley Pub. Co.: Reading, MA, USA, 1975.

13. Davis, F.D. A Technology Acceptance Model for Empirically Testing New End-User Information Systems; Theory and Results; Massachusetts Institute of Technology: Cambridge, MA, USA, 1986.

14. Davis, F. Perceived usefulness, perceived ease of use, and user acceptance of information technology. MIS Q. 1989, 13, 319-340. [CrossRef]

15. Davis, F.D.; Bagozzi, R.P.; Warshaw, P.R. User Acceptance of Computer Technology: A Comparison of Two Theoretical Models. Manag. Sci. 1989, 35, 982-1003. [CrossRef]

16. Venkatesh, V.; Davis, F.D. A theoretical extension of the technology acceptance model: Four longitudinal field studies. Manag. Sci. 2000, 46, 186-204. [CrossRef]

17. Venkatesh, V.; Bala, H. Technology acceptance model 3 and a research agenda on interventions. Decis. Sci. 2008, 39, 273-315. [CrossRef]

18. Venkatesh, V.; Morris, M.; Davis, G.; Davis, F. User acceptance of information technology: Toward a unified view. MIS Q. 2003, 27, 425-478. [CrossRef]

19. Bandura, A. Self-efficacy: Toward a unifying theory of behavioral change. Psychol. Rev. 1977, 84, 191. [CrossRef]

20. Bandura, A. Social Foundations of Thought and Action: A Social Cognitive Theory; Prentice Hall: Englewood Cliffs, NJ, USA, 1986.

21. Triandis, H. Interpersonal Behavior; Brooks/Cole Pub. Co.: Monterey, CA, USA, 1977; ISBN 081850188X 9780818501883.

22. Moore, G.C.; Benbasat, I. Development of an Instrument to Measure the Perceptions of Adopting an Information Technology Innovation. Inf. Syst. Res. 1991, 2, 192-222. [CrossRef]

23. Ajzen, I. From Intentions to Actions: A Theory of Planned Behavior. In Action Control; Springer: Berlin/Heidelberg, Germany, 1985; pp. 11-39, ISBN 978-3-642-69746-3.

24. Thompson, R.L.; Higgins, C.A.; Howell, J.M. Personal Computing: Toward a Conceptual Model of Utilization. MIS Q. 1991, 15, 125-143. [CrossRef]

25. Davis, F.D.; Bagozzi, R.P.; Warshaw, P.R. Extrinsic and intrinsic motivation to use computers in the workplace. J. Appl. Soc. Psychol. 1992, 22, 1111-1132. [CrossRef]

26. Rogers, E.M. Diffusion of Innovations, 4th ed.; Simon and Schuster (Free Press): New York, NY, USA, $1995 ;$ ISBN 1451602472.

27. Igbaria, M.; Schiffman, S.J.; Wieckowski, T.J. The respective roles of perceived usefulness and perceived fun in the acceptance of microcomputer technology. Behav. Inf. Technol. 1994, 13, 349-361. [CrossRef]

28. Bennani, A.E.; Oumlil, R. Factors fostering IT acceptance by nurses in Morocco: Short paper. In Proceedings of the ProceedingsInternational Conference on Research Challenges in Information Science, Paris, France, 29-31 May 2013. 
29. Perlich, A.; Meinel, C.; Zeis, D. Evaluation of the technology acceptance of a collaborative documentation system for addiction therapists and clients. Stud. Health Technol. Inform. 2018, 247, 695-699. [CrossRef] [PubMed]

30. Holden, R.J.; Karsh, B.-T. The Technology Acceptance Model: Its past and its future in health care. J. Biomed. Inform. 2010, 43, 159-172. [CrossRef] [PubMed]

31. Kim, S.; Lee, K.-H.; Hwang, H.; Yoo, S. Analysis of the factors influencing healthcare professionals' adoption of mobile electronic medical record (EMR) using the unified theory of acceptance and use of technology (UTAUT) in a tertiary hospital. BMC Med. Inform. Decis. Mak. 2016, 16, 12. [CrossRef] [PubMed]

32. Al-Emran, M.; Granić, A. Is It Still Valid or Outdated? A Bibliometric Analysis of the Technology Acceptance Model and Its Applications From 2010 to 2020. In Recent Advances in Technology Acceptance Models and Theories; Springer: Berlin/Heidelberg, Germany, 2021.

33. Peek, S.T.M.; Wouters, E.J.M.; van Hoof, J.; Luijkx, K.G.; Boeije, H.R.; Vrijhoef, H.J.M. Factors influencing acceptance of technology for aging in place: A systematic review. Int. J. Med. Inform. 2014, 83, 235-248. [CrossRef]

34. Vaezipour, A.; Whelan, B.M.; Wall, K.; Theodoros, D. Acceptance of Rehabilitation Technology in Adults with Moderate to Severe Traumatic Brain Injury, Their Caregivers, and Healthcare Professionals: A Systematic Review. J. Head Trauma Rehabil. 2019, 34, E67-E82. [CrossRef]

35. Cimperman, M.; Makovec Brenčič, M.; Trkman, P. Analyzing older users' home telehealth services acceptance behavior-applying an Extended UTAUT model. Int. J. Med. Inform. 2016, 90, 22-31. [CrossRef]

36. Goodarzian, F.; Abraham, A.; Ghasemi, P.; Mascolo, M.D.; Nasseri, H. Designing a green home healthcare network using grey flexible linear programming: Heuristic approaches. J. Comput. Des. Eng. 2021, 8, 1468-1498. [CrossRef]

37. Goodarzian, F.; Abraham, A.; Fathollahi-Fard, A.M. A biobjective home health care logistics considering the working time and route balancing: A self-adaptive social engineering optimizer. J. Comput. Des. Eng. 2021, 8, 452-474. [CrossRef]

38. Tubaishat, A. Perceived usefulness and perceived ease of use of electronic health records among nurses: Application of Technology Acceptance Model. Inform. Health Soc. Care 2018, 43, 379-389. [CrossRef]

39. Hadadgar, A.; Changiz, T.; Masiello, I.; Dehghani, Z.; Mirshahzadeh, N.; Zary, N. Applicability of the theory of planned behavior in explaining the general practitioners eLearning use in continuing medical education. BMC Med. Educ. 2016, 16. [CrossRef] [PubMed]

40. McGinn, C.A.; Grenier, S.; Duplantie, J.; Shaw, N.; Sicotte, C.; Mathieu, L.; Leduc, Y.; Légaré, F.; Gagnon, M.-P. Comparison of user groups' perspectives of barriers and facilitators to implementing electronic health records: A systematic review. BMC Med. 2011, 9, 46. [CrossRef]

41. Gagnon, M.-P.; Desmartis, M.; Labrecque, M.; Car, J.; Pagliari, C.; Pluye, P.; Frémont, P.; Gagnon, J.; Tremblay, N.; Légaré, F. Systematic Review of Factors Influencing the Adoption of Information and Communication Technologies by Healthcare Professionals. J. Med. Syst. 2012, 36, 241-277. [CrossRef]

42. Mair, F.S.; May, C.; O’Donnell, C.; Finch, T.; Sullivan, F.; Murray, E. Factors that promote or inhibit the implementation of e-health systems: An explanatory systematic review. Bull. World Health Organ. 2012, 90, 357-364. [CrossRef]

43. Yucel, A.; Gulbahar, U.; Yasemin, Y. Technology Acceptance Model: A Review of the Prior Predictors. Ankara Univ. Egit. Bilim. Fak. Derg. 2013, 46, 89-109. [CrossRef]

44. Gagnon, M.-P.; Ngangue, P.; Payne-Gagnon, J.; Desmartis, M. m-Health adoption by healthcare professionals: A systematic review. J. Am. Med. Inform. Assoc. 2016, 23, 212-220. [CrossRef] [PubMed]

45. Yusif, S.; Soar, J.; Hafeez-Baig, A. Older people, assistive technologies, and the barriers to adoption: A systematic review. Int. J. Med. Inform. 2016, 94, 112-116. [CrossRef] [PubMed]

46. Al-Saedi, K.; Al-Emran, M. A Systematic Review of Mobile Payment Studies from the Lens of the UTAUT Model. In Recent Advances in Technology Acceptance Models and Theories; Springer: Cham, Switzerland, 2021; Volume 335, pp. 79-106.

47. Marangunić, N.; Granić, A. Technology acceptance model: A literature review from 1986 to 2013. Univers. Access Inf. Soc. 2015, 14, 81-95. [CrossRef]

48. Fatehah, M.; Mezhuyev, V.; Al-Emran, M. A Systematic Review of Metamodelling in Software Engineering. In Recent Advances in Intelligent Systems and Smart Applications; Springer: Berlin/Heidelberg, Germany, 2021; pp. 3-27.

49. Kitchenham, B.; Charters, S. Guidelines for performing systematic literature reviews in software engineering. Softw. Eng. Group Sch. Comput. Sci. Math. Keele Univ. 2007, 1-57. Available online: http:// citeseerx.ist.psu.edu/viewdoc/summary?doi=10.1.1.117 .471 (accessed on 2 November 2021).

50. Moher, D.; Liberati, A.; Tetzlaff, J.; Altman, D.G. Preferred reporting items for systematic reviews and meta-analyses: The PRISMA statement. J. Clin. Epidemiol. 2009, 62, 1006-1012. [CrossRef]

51. Moher, D.; Shamseer, L.; Clarke, M.; Ghersi, D.; Liberati, A.; Petticrew, M.; Shekelle, P.; Stewart, L.A. Preferred reporting items for systematic review and meta-analysis protocols (PRISMA-P) 2015 statement. Syst. Rev. 2015, 4, 1-9. [CrossRef]

52. Al-Nuaimi, M.N.; Al-Emran, M. Learning management systems and technology acceptance models: A systematic review. Educ. Inf. Technol. 2021, 1-35. [CrossRef]

53. Mendeley Ltd. Mendeley. Available online: https://www.mendeley.com/ (accessed on 14 March 2020).

54. Al-Emran, M.; Mezhuyev, V.; Kamaludin, A. Technology Acceptance Model in M-learning context: A systematic review. Comput. Educ. 2018, 125, 389-412. [CrossRef] 
55. Al-Emran, M.; Mezhuyev, V.; Kamaludin, A.; Shaalan, K. The impact of knowledge management processes on information systems: A systematic review. Int. J. Inf. Manag. 2018, 43, 173-187. [CrossRef]

56. Al-Qaysi, N.; Mohamad-Nordin, N.; Al-Emran, M. Employing the technology acceptance model in social media: A systematic review. Educ. Inf. Technol. 2020, 1-42. [CrossRef]

57. AlQudah, A.A.; Salloum, S.A.; Shaalan, K. The Role of Technology Acceptance in Healthcare to Mitigate COVID-19 Outbreak. In Studies in Systems, Decision and Control; Springer: Berlin/Heidelberg, Germany, 2021; Volume 348, pp. $223-244$.

58. Gajanayake, R.; Sahama, T.; Iannella, R. The role of perceived usefulness and attitude on electronic health record acceptance. Int. J. E-Health Med. Commun. 2013, 5, 108-119. [CrossRef]

59. Hsu, H.H.; Wu, Y.H. Investigation of the effects of a nursing information system by using the technology acceptance model. CIN-Comput. Inform. Nurs. 2017, 35, 315-322. [CrossRef]

60. Lin, W.-Y.; Ke, H.-L.; Chou, W.-C.; Chang, P.-C.; Tsai, T.-H.; Lee, M.-Y. Realization and Technology Acceptance Test of a Wearable Cardiac Health Monitoring and Early Warning System with Multi-Channel MCGs and ECG. Sensors 2018, 18, 3538. [CrossRef]

61. Özdemir-Güngör, D.; Camgöz-Akdağ, H. Examining the effects of technology anxiety and resistance to change on the acceptance of breast tumor registry system: Evidence from Turkey. Technol. Soc. 2018, 54, 66-73. [CrossRef]

62. Sarlan, A.; Ahmad, R.; Ahmad, W.F.W.; Dominic, D.D. A study of SME private healthcare personnel acceptance of Clinic Information System in Malaysia. Int. J. Bus. Inf. Syst. 2013, 14, 238. [CrossRef]

63. Li, J.; Ma, Q.; Chan, A.H.; Man, S.S. Health monitoring through wearable technologies for older adults: Smart wearables acceptance model. Appl. Ergon. 2019, 75, 162-169. [CrossRef] [PubMed]

64. Tsai, J.M.; Cheng, M.J.; Tsai, H.H.; Hung, S.W.; Chen, Y.L. Acceptance and resistance of telehealth: The perspective of dual-factor concepts in technology adoption. Int. J. Inf. Manag. 2019, 49, 34-44. [CrossRef]

65. Kalavani, A.; Kazerani, M.; Shekofteh, M. Acceptance of evidence based medicine (EBM) databases by Iranian medical residents using unified theory of acceptance and use of technology (UTAUT). Health Policy Technol. 2018, 7, 287-292. [CrossRef]

66. Idoga, P.E.; Toycan, M.; Nadiri, H.; Çelebi, E. Assessing factors militating against the acceptance and successful implementation of a cloud based health center from the healthcare professionals' perspective: A survey of hospitals in Benue state, northcentral Nigeria. BMC Med. Inform. Decis. Mak. 2019, 19, 34. [CrossRef] [PubMed]

67. Beldad, A.D.; Hegner, S.M. Expanding the Technology Acceptance Model with the Inclusion of Trust, Social Influence, and Health Valuation to Determine the Predictors of German Users' Willingness to Continue using a Fitness App: A Structural Equation Modeling Approach. Int. J. Hum.-Comput. Interact. 2018, 34, 882-893. [CrossRef]

68. Liu, M.C.; Lee, C.C. An Investigation of Pharmacists' Acceptance of NHI-PharmaCloud in Taiwan. J. Med. Syst. 2018, 42, 213. [CrossRef] [PubMed]

69. Nadri, H.; Rahimi, B.; Afshar, H.L.; Samadbeik, M.; Garavand, A. Factors affecting acceptance of hospital information systems based on extended technology acceptance model: A case study in three paraclinical departments. Appl. Clin. Inform. 2018, 9, 238-247. [CrossRef]

70. Agarwal, R.; Prasad, J. A Conceptual and Operational Definition of Personal Innovativeness in the Domain of Information Technology. Inf. Syst. Res. 1998, 9, 204-215. [CrossRef]

71. Gefen, D.; Karahanna, E.; Straub, D.W. Trust and TAM in Online Shopping: An Integrated Model. MIS Q. 2003, 27, 51. [CrossRef]

72. Al-Qaysi, N.; Mohamad-Nordin, N.; Al-Emran, M. Factors Affecting the Adoption of Social Media in Higher Education: A Systematic Review of the Technology Acceptance Model. In Recent Advances in Intelligent Systems and Smart Applications; Springer: Berlin/Heidelberg, Germany, 2021; pp. 571-584.

73. Medical Subject Headings-Home Page. Available online: http:/ /www.nlm.nih.gov/mesh/ (accessed on 16 January 2021).

74. Al-Saedi, K.; Al-Emran, M.; Abusham, E.; El-Rahman, S.A. Mobile Payment Adoption: A Systematic Review of the UTAUT Model. In Proceedings of the 2019 International Conference on Fourth Industrial Revolution, ICFIR 2019, Manama, Bahrain, 19-21 February 2019.

75. King, W.R.; He, J. A meta-analysis of the technology acceptance model. Inf. Manag. 2006, 43, 740-755. [CrossRef]

76. Legris, P.; Ingham, J.; Collerette, P. Why do people use information technology? A critical review of the technology acceptance model. Inf. Manag. 2003, 40, 191-204. [CrossRef]

77. Alsharida, R.A.; Hammood, M.M.; Al-Emran, M. Mobile Learning Adoption: A Systematic Review of the Technology Acceptance Model from 2017 to 2020. Int. J. Emerg. Technol. Learn. 2021, 15. [CrossRef]

78. Khan, I.U.; Yu, Y.; Hameed, Z.; Khan, S.U.; Waheed, A. Assessing the Physicians' Acceptance of E-Prescribing in a Developing Country: An Extension of the UTAUT Model With Moderating Effect of Perceived Organizational Support. J. Glob. Inf. Manag. 2018, 26, 121-142. [CrossRef]

79. Schaper, L.K.; Pervan, G.P. ICT and OTs: A model of information and communication technology acceptance and utilisation by occupational therapists. Int. J. Med. Inform. 2007, 76, S212-S221. [CrossRef] [PubMed]

80. Turja, T.; Aaltonen, I.; Taipale, S.; Oksanen, A. Robot acceptance model for care (RAM-care): A principled approach to the intention to use care robots. Inf. Manag. 2019, 103220. [CrossRef]

81. Wu, T.-Y.; Majeed, A.; Kuo, K.N. An overview of the healthcare system in Taiwan. Lond. J. Prim. Care 2010, 3, 115-119. [CrossRef] [PubMed]

82. Goodarzian, F.; Ghasemi, P.; Gunasekaren, A.; Taleizadeh, A.A.; Abraham, A. A sustainable-resilience healthcare network for handling COVID-19 pandemic. Ann. Oper. Res. 2021, 1-65. [CrossRef] 
83. Arpaci, I.; Alshehabi, S.; Al-Emran, M.; Khasawneh, M.; Mahariq, I.; Abdeljawad, T.; Hassanien, A.E. Analysis of Twitter Data Using Evolutionary Clustering during the COVID-19 Pandemic. Comput. Mater. Contin. 2020, 65, 193-203. [CrossRef]

84. Bennani, A.E.; Oumlil, R. Do constructs of technology acceptance model predict the ICT appropriation by physicians and nurses in healthcare public centres in Agadir, South of Morocco? In Proceedings of the HEALTHINF 2010-3rd International Conference on Health Informatics, Valencia, Spain, 20-23 January 2010; pp. 241-249.

85. Lai, D.W.; Li, Y.P. Examining the technology acceptance model of the computer assistance orthopedic surgery system. In Proceedings of the 2010 7th International Conference on Service Systems and Service Management (ICSSSM' 10), Tokyo, Japan, 28-30 June 2010; pp. 940-945.

86. Kim, J.; DelliFraine, J.L.; Dansky, K.H.; McCleary, K.J. Physicians' acceptance of telemedicine technology: An empirical test of competing theories. Int. J. Inf. Syst. Chang. Manag. 2010, 4, 210-225. [CrossRef]

87. Holtz, B.E. An Examination of the Adoption of Electronic Medical Records by Rural Hospital Nurses through the Unified Theory of Acceptance and Use of Technology Lens; Michigan State University: East Lansing, MI, USA, 2010; Volume 72.

88. Pai, F.Y.; Huang, K.I. Applying the Technology Acceptance Model to the introduction of healthcare information systems. Technol. Forecast. Soc. Chang. 2011, 78, 650-660. [CrossRef]

89. Orruño, E.; Gagnon, M.P.; Asua, J.; Abdeljelil, A. Ben Evaluation of teledermatology adoption by health-care professionals using a modified Technology Acceptance Model. J. Telemed. Telecare 2011, 17, 303-307. [CrossRef]

90. Maarop, N.; Win, K.T.; Masrom, M.; Hazara Singh, S.S. Exploring teleconsultation acceptance: A comparison study between emergency and non-emergency setting. In Proceedings of the 2011 International Conference on Research and Innovation in Information Systems (ICRIIS'11, IEEE), Kuala Lumpur, Malaysia, 23-24 November 2011; pp. 1-5.

91. Schnall, R.; Bakken, S. Testing the Technology Acceptance Model: HIV case managers' intention to use a continuity of care record with context-specific links. Inform. Health Soc. Care 2011, 36, 161-172. [CrossRef]

92. Kowitlawakul, Y. The technology acceptance model: Predicting nurses' intention to use telemedicine technology (eICU). CINComput. Inform. Nurs. 2011, 29, 411-418. [CrossRef]

93. Damanhoori, F.; Zakaria, N.; Hooi, L.Y.; Sultan, N.A.H.; Talib, N.A.; Ramadass, S. Understanding users' Technology Acceptance on Breast Self Examination teleconsultation. In Proceedings of the 8th International Conference on High-capacity Optical Networks and Emerging Technologies (IEEE), Riyadh, Saudi Arabia, 19-21 December 2011; pp. 374-380.

94. Lim, S.; Xue, L.; Yen, C.C.; Chang, L.; Chan, H.C.; Tai, B.C.; Duh, H.B.L.; Choolani, M. A study on Singaporean women's acceptance of using mobile phones to seek health information. Int. J. Med. Inform. 2011, 80, e189-e202. [CrossRef] [PubMed]

95. Mohamed, A.H.H.M.; Tawfik, H.; Norton, L.; Al-Jumeily, D. e-HTAM: A Technology Acceptance Model for electronic health. In Proceedings of the 2011 International Conference on Innovations in Information Technology, Abu Dhabi, United Arab Emirates, 25-27 April 2011; pp. 134-138.

96. Ortega Egea, J.M.; Román González, M.V. Explaining physicians' acceptance of EHCR systems: An extension of TAM with trust and risk factors. Comput. Hum. Behav. 2011, 27, 319-332. [CrossRef]

97. Mohamed, A.H.H.M.; Tawfik, H.; Al-Jumeily, D.; Norton, L. MoHTAM: A Technology Acceptance Model for Mobile Health Applications. In Proceedings of the 2011 Developments in E-systems Engineering (IEEE), Dubai, United Arab Emirates, 6-8 December 2011; pp. 13-18.

98. Chong, A.Y.-L.; Chan, F.T.S. Understanding the Acceptance of RFID in the Healthcare Industry: Extending the TAM Model. In Decision-Making for Supply Chain Integration; Springer: Berlin/Heidelberg, Germany, 2012; pp. 105-122.

99. Kim, J.; Park, H.A. Development of a health information technology acceptance model using consumers' health behavior intention. J. Med. Internet Res. 2012, 14, e133. [CrossRef] [PubMed]

100. Terrizzi, S.; Sherer, S.; Meyerhoefer, C.; Sheinberg, M.; Levick, D. Extending the technology acceptance model in healthcare: Identifying the role of trust and shared information. In Proceedings of the 18th Americas Conference on Information Systems 2012 (AMCIS 2012), Seattle, WA, USA, 9-11 August 2012; Volume 6, pp. 4518-4527.

101. Chow, M.; Herold, D.K.; Choo, T.-M.; Chan, K. Extending the technology acceptance model to explore the intention to use Second Life for enhancing healthcare education. Comput. Educ. 2012, 59, 1136-1144. [CrossRef]

102. Asua, J.; Orruño, E.; Reviriego, E.; Gagnon, M.P. Healthcare professional acceptance of telemonitoring for chronic care patients in primary care. BMC Med. Inform. Decis. Mak. 2012, 12, 139. [CrossRef] [PubMed]

103. Khalika Banda, C.; Gombachika, H. Mobile phone technology acceptance and usability in the delivery of health services among health surveillance assistants in rural areas of Malawi. In International Conference on e-Infrastructure and e-Services for Developing Countries (AFRICOMM 2012); Springer: Berlin/Heidelberg, Germany, 2013; Volume 119, pp. 249-258.

104. Holden, R.J.; Brown, R.L.; Scanlon, M.C.; Karsh, B.T. Pharmacy workers' perceptions and acceptance of bar-coded medication technology in a pediatric hospital. Res. Soc. Adm. Pharm. 2012, 8, 509-522. [CrossRef]

105. Chang, I.C.; Hsu, H.M. Predicting medical staff intention to use an online reporting system with modified unified theory of acceptance and use of technology. Telemed. e-Health 2012, 18, 67-73. [CrossRef]

106. Ifinedo, P. Technology acceptance by health professionals in Canada: An analysis with a modified UTAUT model. In Proceedings of the 45th Hawaii International Conference on System Sciences, Maui, HI, USA, 4-7 January 2012; pp. $2937-2946$.

107. Moores, T.T. Towards an integrated model of IT acceptance in healthcare. Decis. Support Syst. 2012, 53, 507-516. [CrossRef] 
108. Guo, X.; Yuan, J.; Cao, X.; Chen, X. Understanding the acceptance of mobile health services: A service participants analysis. In Proceedings of the 2012 International Conference on Management Science \& Engineering 19th Annual Conference Proceedings, Dallas, TX, USA, 20-22 September 2012; pp. 1868-1873.

109. Sarlan, A.; Ahmad, R.; Wan Ahmad, W.F.; Dominic, P.D.D. Users' behavioral intention to use clinic information system: A survey. In Proceedings of the 2012 International Conference on Computer and Information Science, ICCIS 2012-A Conference of World Engineering, Science and Technology Congress, ESTCON 2012_Conference Proceedings, Kuala Lumpur, Malaysia, 12-14 June 2012; Volume 1, pp. 37-43.

110. Gagnon, M.P.; Orruño, E.; Asua, J.; Abdeljelil, A.B.; Emparanza, J. Using a modified technology acceptance model to evaluate healthcare professionals' adoption of a new telemonitoring system. Telemed. e-Health 2012, 18, 54-59. [CrossRef]

111. Chua, J.C.; Foo, M.H.; Cheong, Y.L.; Ng, J.; Toh, C.K. Using paper prototyping to assess the perceived acceptance of MedMate: A home-based pill dispenser. In Proceedings of the 2012 Southeast Asian Network of Ergonomics Societies Conference: Ergonomics Innovations Leveraging User Experience and Sustainability (SEANES 2012), Langkawi, Malaysia, 9-12 July 2012.

112. Su, S.P.; Tsai, C.H.; Chen, Y.K. Applying the technology acceptance model to explore intention to use telecare system in Taiwan. In Proceedings of the Proceedings-13th ACIS International Conference on Software Engineering, Artificial Intelligence, Networking, and Parallel/Distributed Computing (SNPD 2012), Kyoto, Japan, 8-10 August 2012; pp. 353-356.

113. Chow, M.; Chan, L.; Lo, B.; Chu, W.P.; Chan, T.; Lai, Y.M. Exploring the intention to use a clinical imaging portal for enhancing healthcare education. Nurse Educ. Today 2013, 33, 655-662. [CrossRef]

114. Cheng, Y.M. Exploring the roles of interaction and flow in explaining nurses' e-learning acceptance. Nurse Educ. Today 2013, 33, 73-80. [CrossRef] [PubMed]

115. Vanneste, D.; Vermeulen, B.; Declercq, A. Healthcare professionals' acceptance of BelRAI, a web-based system enabling personcentred recording and data sharing across care settings with interRAI instruments: A UTAUT analysis. BMC Med. Inform. Decis. Mak. 2013, 13, 129. [CrossRef]

116. Huang, J.C. Innovative health care delivery system-A questionnaire survey to evaluate the influence of behavioral factors on individuals' acceptance of telecare. Comput. Biol. Med. 2013, 43, 281-286. [CrossRef]

117. Escobar-Rodríguez, T.; Romero-Alonso, M.M. Modeling nurses' attitude toward using automated unit-based medication storage and distribution systems: An extension of the technology acceptance model. CIN-Comput. Inform. Nurs. 2013, 31, 235-243. [CrossRef]

118. Arning, K.; Kowalewski, S.; Ziefle, M. Modelling user acceptance of wireless medical technologies. In Proceedings of the Lecture Notes of the Institute for Computer Sciences, Social-Informatics and Telecommunications Engineering (LNICST), Paris, France, 7-8 November 2013; Volume 61, pp. 146-153.

119. Sarlan, A.; Ahmad, R.; Fatimah, W.; Ahmad, W.; Dominic, P.D.D. Private Healthcare in Malaysia: Investigation on Technology Profiles and Technology Acceptance Factors. In Proceedings of the Information Systems International Conference (ISICO), Bali, Indonesia, 2-4 December 2013; pp. 98-103.

120. Cocosila, M. Role of user a priori attitude in the acceptance of mobile health: An empirical investigation. Electron. Mark. 2013, 23, 15-27. [CrossRef]

121. Chen, S.C.; Liu, S.C.; Li, S.H.; Yen, D.C. Understanding the mediating effects of relationship quality on technology acceptance: An empirical study of E-appointment system. J. Med. Syst. 2013, 37. [CrossRef] [PubMed]

122. Kummer, T.F.; Schäfer, K.; Todorova, N. Acceptance of hospital nurses toward sensor-based medication systems: A questionnaire survey. Int. J. Nurs. Stud. 2013, 50, 508-517. [CrossRef]

123. Kuo, K.M.; Liu, C.F.; Ma, C.C. An investigation of the effect of nurses' technology readiness on the acceptance of mobile electronic medical record systems. BMC Med. Inform. Decis. Mak. 2013, 13, 1-14. [CrossRef]

124. Krueklai, S.; Kiattisin, S.; Leelasantitham, A. Analysis of factor affecting in unified theory of acceptance and use of technology (UTAUT) e-healthcare of government hospitals in Thailand. Int. Conf. Inf. Soc. Sci. Int. Symp. Mark. Logist. Bus. 2013, 443-451.

125. Manimaran, S.; Lakshmi, K.B. Development of model for assessing the acceptance level of users in rural healthcare system of Tamilnadu, India. Technol. Health Care 2013, 21, 479-492. [CrossRef] [PubMed]

126. Tavakoli, N.; Jahanbakhsh, M.; Shahin, A.; Mokhtari, H.; Rafiei, M. Electronic medical record in central polyclinic of isfahan oil industry: A case study based on technology acceptance model. Acta Inform. Medica 2013, 21, 23-25. [CrossRef] [PubMed]

127. Jackson, J.D.; Yi, M.Y.; Park, J.S. An empirical test of three mediation models for the relationship between personal innovativeness and user acceptance of technology. Inf. Manag. 2013, 50, 154-161. [CrossRef]

128. Mohamed, A.H.H.M.; Tawfik, H.; Norton, L.; Al-Jumeily, D. A Technology Acceptance Model for a User-Centred CulturallyAware E-Health Design. In Proceedings of the 2013 Sixth International Conference on Developments in eSystems Engineering (IEEE), Abu Dhabi, United Arab Emirates, 16-18 December 2013; pp. 121-125.

129. Ford, S. "Drew" Age, Performance and Retention Interval Effects on Acceptance of a Consumer Health Information Technology System; Louisiana State University: Baton Rouge, LA, USA, 2014.

130. Alaiad, A.; Zhou, L.; Koru, G. An exploratory study of home healthcare robots adoption applying the UTAUT model. Int. J. Healthc. Inf. Syst. Inform. 2014, 9, 44-59. [CrossRef]

131. Lin, H.C. An investigation of the effects of cultural differences on physicians' perceptions of information technology acceptance as they relate to knowledge management systems. Comput. Hum. Behav. 2014, 38, 368-380. [CrossRef] 
132. Hsieh, P.J.; Lai, H.M.; Ye, Y.S. Patients' acceptance and resistance toward the health cloud: An integration of technology acceptance and status quo bias perspectives. In Proceedings of the Proceedings-Pacific Asia Conference on Information Systems (PACIS 2014), Chengdu, China, 24-28 June 2014.

133. Gagnon, M.P.; Ghandour, E.K.; Talla, P.K.; Simonyan, D.; Godin, G.; Labrecque, M.; Ouimet, M.; Rousseau, M. Electronic health record acceptance by physicians: Testing an integrated theoretical model. J. Biomed. Inform. 2014, 48, 17-27. [CrossRef]

134. Fleming, M.L.; Hatfield, M.D.; Wattana, M.K.; Todd, K.H. Exploratory study of emergency physicians' use of a prescription monitoring program using a framework of technology acceptance. J. Pain Palliat. Care Pharmacother. 2014, 28, 19-27. [CrossRef]

135. Corneille, M.; Carter, L.; Hall-Byers, N.M.; Clark, T.; Younge, S. Exploring user acceptance of a text-message based health intervention. In Proceedings of the Annual Hawaii International Conference on System Sciences, Waikoloa, HI, USA, 6-9 January 2014; pp. 2759-2767.

136. Steininger, K.; Stiglbauer, B.; Baumgartner, B.; Engleder, B. Factors explaining physicians' acceptance of electronic health records. In Proceedings of the Annual Hawaii International Conference on System Sciences, Waikoloa, HI, USA, 6-9 January 2014; pp. 2768-2777.

137. Hwang, J.Y.; Kim, K.Y.; Lee, K.H. Factors that influence the acceptance of telemetry by emergency medical technicians in ambulances: An application of the extended technology acceptance model. Telemed. e-Health 2014, 20, 1127-1134. [CrossRef]

138. Hung, S.Y.; Tsai, J.C.A.; Chuang, C.C. Investigating primary health care nurses' intention to use information technology: An empirical study in Taiwan. Decis. Support Syst. 2014, 57, 331-342. [CrossRef]

139. Rho, M.J.; young Choi, I.; Lee, J. Predictive factors of telemedicine service acceptance and behavioral intention of physicians. Int. J. Med. Inform. 2014, 83, 559-571. [CrossRef]

140. Moon, B.C.; Chang, H. Technology acceptance and adoption of innovative smartphone uses among hospital employees. Healthc. Inform. Res. 2014, 20, 304-312. [CrossRef]

141. Tsai, C.H. The adoption of a telehealth system: The integration of extended technology acceptance model and health belief model. J. Med. Imaging Health Inform. 2014, 4, 448-455. [CrossRef]

142. Yallah, A. A Correlational Study of the Technology Acceptance Model and Georgia Behavioral Healthcare Provider Telemedicine Adoption; Northcentral University: Scottsdale, AZ, USA, 2014; Volume 3622519.

143. Cleveland, S.D. Factors Predicting Nurse Educators' Acceptance and Use of Educational Technology in Classroom Instruction. Ph.D. Thesis, Capella University, Minneapolis, MN, USA, 2014.

144. Devine, D.A. Assessment of Nurse Faculty's Acceptance and Intent to Use Social Media Using the Unified Theory of Acceptance and Use of Technology 2 Model; Villanova University: Villanova, PA, USA, 2015.

145. Ebie, S.; Njoku, E. Extension of the technology acceptance model (TAM) to the adoption of the electronic knowledge and skills framework (E-KSF) in the national health service (NHS). J. Appl. Sci. Dev. 2015, 6, 19-50.

146. Krishnan, S.B.; Dhillon, J.S.; Lutteroth, C. Factors influencing consumer intention to adopt Consumer Health Informatics applications an empirical study in Malaysia. In Proceedings of the 2015 IEEE Student Conference on Research and Development (SCOReD 2015), Kuala Lumpur, Malaysia, 13-14 December 2015; pp. 653-658.

147. Basak, E.; Gumussoy, C.A.; Calisir, F. Examining the factors affecting PDA acceptance among physicians: An extended technology acceptance model. J. Healthc. Eng. 2015, 6, 399-418. [CrossRef]

148. Briz-Ponce, L.; García-Peñalvo, F.J. An empirical assessment of a technology acceptance model for apps in medical education. J. Med. Syst. 2015, 39, 176. [CrossRef]

149. Song, L.; Park, B.; Oh, K.M. Analysis of the Technology Acceptance Model in Examining Hospital Nurses' Behavioral Intentions Toward the Use of Bar Code Medication Administration. CIN_Comput. Inform. Nurs. 2015, 33, 157-165. [CrossRef] [PubMed]

150. Holahan, P.J.; Lesselroth, B.J.; Adams, K.; Wang, K.; Church, V. Beyond technology acceptance to effective technology use: A parsimonious and actionable model. J. Am. Med. Inform. Assoc. 2015, 22, 718-729. [CrossRef] [PubMed]

151. Ahadzadeh, A.S.; Pahlevan Sharif, S.; Ong, F.S.; Khong, K.W. Integrating Health Belief Model and Technology Acceptance Model: An investigation of health-related Internet use. J. Med. Internet Res. 2015, 17, e3564. [CrossRef] [PubMed]

152. Kowitlawakul, Y.; Chan, S.W.C.; Pulcini, J.; Wang, W. Factors influencing nursing students' acceptance of electronic health records for nursing education (EHRNE) software program. Nurse Educ. Today 2015, 35, 189-194. [CrossRef]

153. Elaklouk, A.M.; Mat Zin, N.A.; Shapii, A. Investigating therapists' intention to use serious games for acquired brain injury cognitive rehabilitation. J. King Saud Univ.-Comput. Inf. Sci. 2015, 27, 160-169. [CrossRef]

154. Chang, M.Y.; Pang, C.; Michael Tarn, J.; Liu, T.S.; Yen, D.C. Exploring user acceptance of an e-hospital service: An empirical study in Taiwan. Comput. Stand. Interfaces 2015, 38, 35-43. [CrossRef]

155. Hsieh, P.J. Healthcare professionals' use of health clouds: Integrating technology acceptance and status quo bias perspectives. Int. J. Med. Inform. 2015, 84, 512-523. [CrossRef] [PubMed]

156. Steininger, K.; Stiglbauer, B. EHR acceptance among Austrian resident doctors. Health Policy Technol. 2015, 4, 121-130. [CrossRef]

157. De Veer, A.J.E.; Peeters, J.M.; Brabers, A.E.M.; Schellevis, F.G.; Rademakers, J.J.D.J.M.; Francke, A.L. Determinants of the intention to use e-health by community dwelling older people. BMC Health Serv. Res. 2015, 15, 103. [CrossRef]

158. Ku, W.T.; Hsieh, P.J. Taiwanese middle-aged and elderly patients' acceptance and resistance toward the health cloud. In Proceedings of the International Conference on Human Aspects of IT for the Aged Population, Los Angeles, CA, USA, 2-7 August 2015; Springer: Berlin/Heidelberg, Germany; Volume 9194, pp. 89-100. 
159. Liu, C.F.; Cheng, T.J. Exploring critical factors influencing physicians' acceptance of mobile electronic medical records based on the dual-factor model: A validation in Taiwan. BMC Med. Inform. Decis. Mak. 2015, 15, 4. [CrossRef]

160. Miiro, E.; Maiga, G. A model of e-health acceptance and usage in uganda: The perspective of online social networks. In Proceedings of the International Conference on e-Infrastructure and e-Services for Developing Countries, Kampala, Uganda, 24-25 November 2015; Springer: Berlin/Heidelberg, Germany; Volume 147, pp. 115-126.

161. Zaman, N. An Investigation of Nurse Technology Training and Acceptance of Electronic Documentation Systems (e.g., EHR, EMR, EPR); North Carolina A\&T State University: Greensboro, NC, USA, 2015.

162. Sezgin, E.; Özkan-Yıldırım, S. A cross-sectional investigation of acceptance of health information technology: A nationwide survey of community pharmacists in Turkey. Res. Soc. Adm. Pharm. 2016, 12, 949-965. [CrossRef]

163. Mansur, F.; Cakmak, E.K. A Study for determining the variables having impact on health manager's acceptance and use of technology: Example of ankara province. Int. J. Health Manag. Tour. 2016, 1, 37-55.

164. Moon, Y.J.; Hwang, Y.H. A study of effects of UTAUT-based factors on acceptance of smart health care services. In Advanced Multimedia and Ubiquitous Engineering; Springer: Berlin/Heidelberg, Germany, 2016; Volume 354, pp. 317-324, ISBN 9783662478943.

165. Ku, W.T.; Hsieh, P.J. Acceptance of cloud-based healthcare services by elderly Taiwanese people. In Proceedings of the International Conference on Human Aspects of IT for the Aged Population, Toronto, ON, Canada, 17-22 July 2016; Springer: Berlin/Heidelberg, Germany; Volume 9754, pp. 186-195.

166. Made Dhanar, I.Y.; Reza, M.; Meyliana; Widjaja, H.A.E.; Hidayanto, A.N. Acceptance of HIS usage level in hospital with SEM-PLS as analysis methodology: Case study of a private hospital in Indonesia. In Proceedings of the 2016 International Conference on Information Management and Technology (ICIMTech 2016), Bandung, Indonesia, 16-18 November 2016; pp. $112-117$.

167. Hsiao, J.L.; Chen, R.F. Critical factors influencing physicians' intention to use computerized clinical practice guidelines: An integrative model of activity theory and the technology acceptance model. BMC Med. Inform. Decis. Mak. 2016, 16. [CrossRef]

168. Lazard, A.J.; Watkins, I.; Mackert, M.S.; Xie, B.; Stephens, K.K.; Shalev, H. Design simplicity influences patient portal use: The role of aesthetic evaluations for technology acceptance. J. Am. Med. Inform. Assoc. 2016, 23, e157-e161. [CrossRef] [PubMed]

169. Lin, W.Y.; Chou, W.C.; Tsai, T.H.; Lin, C.C.; Lee, M.Y. Development of a wearable instrumented vest for posture monitoring and system usability verification based on the technology acceptance model. Sensors 2016, 16, 2172. [CrossRef]

170. Al-Nassar, B.A.Y.; Rababah, K.A.; Al-Nsour, S.N. Impact of computerised physician order entry in Jordanian hospitals by using technology acceptance model. Int. J. Inf. Syst. Chang. Manag. 2016, 8, 191-210. [CrossRef]

171. Lazuras, L.; Dokou, A. Mental health professionals' acceptance of online counseling. Technol. Soc. 2016, 44, 10-14. [CrossRef]

172. Ifinedo, P.; Griscti, O.; Bailey, J.; Profit, S. Nova Scotia Nurses' Acceptance of Healthcare Information Systems: Focus on Technology Characteristics and Related Factors. Can. J. Nurs. Inform. 2016, 11, 1-13.

173. Holden, R.J.; Asan, O.; Wozniak, E.M.; Flynn, K.E.; Scanlon, M.C. Nurses' perceptions, acceptance, and use of a novel in-room pediatric ICU technology: Testing an expanded technology acceptance model. BMC Med. Inform. Decis. Mak. 2016, 16, 145. [CrossRef] [PubMed]

174. Ducey, A.J.; Coovert, M.D. Predicting tablet computer use: An extended Technology Acceptance Model for physicians. Health Policy Technol. 2016, 5, 268-284. [CrossRef]

175. Chen, M.S.; Chang, S.W.; Lai, Y.H. The intention to use the cloud sphygmomanometer-demonstrated by Taiwan medical center. In Proceedings of the Proceedings-2016 9th International Congress on Image and Signal Processing, BioMedical Engineering and Informatics (CISP-BMEI 2016), Datong, China, 15-17 October 2016; pp. 1843-1848.

176. Guo, X.; Zhang, X.; Sun, Y. The privacy-personalization paradox in mHealth services acceptance of different age groups. Electron. Commer. Res. Appl. 2016, 16, 55-65. [CrossRef]

177. Becker, D. Acceptance of Mobile Mental Health Treatment Applications. Procedia Comput. Sci. 2016, 58, 220-227. [CrossRef]

178. Shujen Lee, C.; Chen, J.K. 3D bio-printing in medical treatment: A technology acceptance model. In Proceedings of the PICMET 2016-Portland International Conference on Management of Engineering and Technology: Technology Management for Social Innovation, Honolulu, HI, USA, 4-8 September 2016; pp. 3149-3154.

179. Hsieh, P.J. An empirical investigation of patients' acceptance and resistance toward the health cloud: The dual factor perspective. Comput. Hum. Behav. 2016, 63, 959-969. [CrossRef]

180. Jayusman, H.; Setyohadi, D.B. An empirical investigations of user acceptance of "Scalsa" e-learning in stikes Harapan Bangsa Purwokerto. In Proceedings of the 2017 5th International Conference on Cyber and IT Service Management (CITSM 2017), Denpasar, Indonesia, 8-10 August 2017.

181. Ul Amin, R.; Inayat, I.; Shahzad, B.; Saleem, K.; Aijun, L. An empirical study on acceptance of secure healthcare service in Malaysia, Pakistan, and Saudi Arabia: A mobile cloud computing perspective. Ann. Telecommun. 2017, 72, 253-264. [CrossRef]

182. Ehteshami, A. Barcode Technology Acceptance and Utilization in Health Information Management Department at Academic Hospitals According to Technology Acceptance Model. Acta Inform. Medica 2017, 25, 4. [CrossRef]

183. Beglaryan, M.; Petrosyan, V.; Bunker, E. Development of a tripolar model of technology acceptance: Hospital-based physicians' perspective on EHR. Int. J. Med. Inform. 2017, 102, 50-61. [CrossRef] [PubMed]

184. Rajanen, D.; Weng, M. Digitization for fun or reward? A study of acceptance of wearable devices for personal healthcare. In Proceedings of the 21st International Academic Mindtrek Conference, Tampere, Finland, 20-21 September 2017; AcademicMindtrek 2017. Association for Computing Machinery, Inc.: New York, NY, USA, 2017; Volume 2017-Janua. 
185. Wahyuni, R. Nurbojatmiko Explaining acceptance of e-health services: An extension of TAM and health belief model approach. In Proceedings of the 2017 5th International Conference on Cyber and IT Service Management (CITSM 2017), Denpasar, Indonesia, 8-10 August 2017.

186. Nematollahi, M.; Moosavi, A.; Lazem, M.; Aslani, N.; Kafashi, M.; Garavand, A. Factors affecting in adoption and use of electronic medical record based on unified theory of acceptance and use of technology in Iran. Shiraz E Med. J. 2017, 18, 57582. [CrossRef]

187. Horne, M.E.P. The Technology Acceptance Model and Telemedicine: Predicting Health Care Providers' Intention to Use Telemedicine; University of Phoenix: Phoenix, AZ, USA, 2017.

188. Hsieh, P.-J.; Lai, H.-M.; Ku, H.-C.; Ku, W.-T. Understanding Middle-Aged and Elderly Taiwanese People's Acceptance of the Personal Health Information System for Self-health Management. In Human Aspects of IT for the Aged Population. Applications, Services and Contexts; Springer: Berlin/Heidelberg, Germany, 2017; Volume 10298, pp. 393-403. ISBN 9783319585352.

189. Lin, H.C. Nurses' satisfaction with using nursing information systems from technology acceptance model and information systems success model perspectives. CIN-Comput. Inform. Nurs. 2017, 35, 91-99. [CrossRef]

190. Dou, K.; Yu, P.; Deng, N.; Liu, F.; Guan, Y.; Li, Z.; Ji, Y.; Du, N.; Lu, X.; Duan, H. Patients' Acceptance of Smartphone Health Technology for Chronic Disease Management: A Theoretical Model and Empirical Test. JMIR mHealth uHealth 2017, 5, e177. [CrossRef] [PubMed]

191. Zhang, X.; Han, X.; Dang, Y.; Meng, F.; Guo, X.; Lin, J. User acceptance of mobile health services from users' perspectives: The role of self-efficacy and response-efficacy in technology acceptance. Inform. Health Soc. Care 2017, 42, 194-206. [CrossRef]

192. Martins, O.; Oyedeji, A.; Abolade, R.; Folorunsho, O. An Empirical Study of Unified Theory of Acceptance and Use of Technology Model for E-Health Technology in Lagos, Nigeria. Futo J. Ser. 2018, 4, 117-126.

193. Aldosari, B.; Al-Mansour, S.; Aldosari, H.; Alanazi, A. Assessment of factors influencing nurses acceptance of electronic medical record in a Saudi Arabia hospital. Inform. Med. Unlocked 2018, 10, 82-88. [CrossRef]

194. Ku, W.T.; Hsieh, P.J. Understanding the acceptance of health management mobile services: Integrating theory of planned behavior and health belief model. In Proceedings of the International Conference on Human-Computer Interaction, Las Vegas, NV, USA, 15-20 July 2018; Springer: Berlin/Heidelberg, Germany; Volume 850, pp. 247-252.

195. Hennemann, S.; Witthöft, M.; Bethge, M.; Spanier, K.; Beutel, M.E.; Zwerenz, R. Acceptance and barriers to access of occupational e-mental health: Cross-sectional findings from a health-risk population of employees. Int. Arch. Occup. Environ. Health 2018, 91, 305-316. [CrossRef]

196. Vitari, C.; Ologeanu-Taddei, R. The intention to use an electronic health record and its antecedents among three different categories of clinical staff. BMC Health Serv. Res. 2018, 18, 194. [CrossRef]

197. Zhou, M.; Zhao, L.; Kong, N.; Campy, K.S.; Qu, S.; Wang, S. Factors influencing behavior intentions to telehealth by Chinese elderly: An extended TAM model. Int. J. Med. Inform. 2019, 126, 118-127. [CrossRef]

198. Francis, R.P. Examining healthcare providers' acceptance of data from patient self-monitoring devices using structural equation modeling with the UTAUT2 model. Int. J. Healthc. Inf. Syst. Inform. 2019, 14, 44-60. [CrossRef]

199. Tao, D.; Shao, F.; Wang, H.; Yan, M.; Qu, X. Integrating usability and social cognitive theories with the technology acceptance model to understand young users' acceptance of a health information portal. Health Inform. J. 2019, 146045821987933. [CrossRef] [PubMed]

200. Masyarakat, J.K.; Nurhayati1, S.; Anandari1, D.; Ekowati, W. Unified Theory of Acceptance and Usage of Technology (UTAUT) Model to Predict Health Information System Adoption. KEMAS J. Kesehat. Masy. 2019, 15, 89-97. [CrossRef]

201. Schomakers, E.M.; Lidynia, C.; Ziefle, M. Listen to My Heart? How Privacy Concerns Shape Users' Acceptance of e-Health Technologies. In Proceedings of the International Conference on Wireless and Mobile Computing, Networking and Communications, Barcelona, Spain, 21-23 October 2019; Volume 2019-Octob, pp. 306-311. 